\title{
Exhumation of the central Wasatch Mountains, Utah: 1. Patterns and timing of exhumation deduced from low-temperature thermochronology data
}

\author{
Phillip A. Armstrong, ${ }^{1}$ Todd A. Ehlers, ${ }^{2,3}$ David S. Chapman, ${ }^{2}$ Kenneth A. Farley, ${ }^{4}$ \\ and Peter J. J. Kamp ${ }^{5}$
}

Received 11 December 2001; revised 27 September 2002; accepted 1 October 2002; published 29 March 2003.

[1] The Wasatch Mountains are often cited as an example of normal fault growth and footwall flexure. They represent a tilted footwall at the edge of the Basin and Range extensional province, a major rift basin. Thus understanding the detailed spatial and elevation changes in coupled thermochronometer data, and how these changes can be interpreted, may aid in the analysis of thermochronometer data from other extensional regions around the world. We present a dense data set from the Cottonwood Intrusive Belt (CIB) of the Wasatch that includes apatite fission track (AFT), zircon fission track (ZFT), and apatite (U-Th)/He ages. ZFT, AFT, and apatite (U-Th)/He ages are 10, 5, and $3 \mathrm{Ma}$, respectively, adjacent to the Wasatch fault. AFT and (U-Th)/He ages increase slightly with distance east of the fault until about $15-20 \mathrm{~km}$, where a more abrupt increase in these ages occurs at or near the Silver Fork-Superior fault zone. ZFT and AFT ages are concordant with 31-38 Ma pluton emplacement ages on the eastern side of range. Modeling of the data leads to the following interpretation: (1) Early cooling and $\sim 3-4 \mathrm{~km}$ of exhumation for the middle and eastern parts of the range occurred in the late Oligocene-middle Miocene. (2) Beginning at 10-12 Ma, the locus of exhumation shifted westward toward the present range front, where the rocks cooled from $>200^{\circ} \mathrm{C}$ in the last $10-12 \mathrm{Myr}$. Our data and interpretations are consistent with a model in which the locus of faulting and exhumation shifted opposite the direction of tilt, similar to that predicted by rolling-hinge extensional models. However, this westward shift and rapid Miocene to recent exhumation may be a local effect superimposed on lower fault displacement and exhumation rates elsewhere along the Wasatch. INDEX TERMS: 8109 Tectonophysics: Continental tectonics-extensional (0905); 1035 Geochemistry: Geochronology; 8010 Structural Geology: Fractures and faults; 8015 Structural Geology: Local crustal structure; KEYWORDS: Wasatch Mountains, exhumation, fission track, helium dating

Citation: Armstrong, P. A., T. A. Ehlers, D. S. Chapman, K. A. Farley, and P. J. J. Kamp, Exhumation of the central Wasatch Mountains, Utah: 1. Patterns and timing of exhumation deduced from low-temperature thermochronology data, J. Geophys. Res., 108(B3), 2172, doi:10.1029/2001JB001708, 2003.

\section{Introduction}

[2] The Wasatch Mountains extend $\sim 400 \mathrm{~km}$ through northern Utah (Figure 1) and are often cited as an example of normal fault growth [e.g., Cowie and Scholz, 1992] and footwall flexure that typify continental rift flank uplift and exhumation [e.g., Zandt and Owens, 1980; Wernicke

\footnotetext{
${ }^{1}$ Department of Geological Sciences, California State University, Fullerton, Fullerton, California, USA.

${ }^{2}$ Department of Geology and Geophysics, University of Utah, Salt Lake City, Utah, USA.

${ }^{3}$ Now at Department of Geological Sciences, University of Michigan, Ann Arbor, Michigan, USA.

${ }^{4}$ Division of Geological and Planetary Sciences, California Institute of Technology, Pasadena, California, USA.

${ }^{5}$ Department of Earth Sciences, University of Waikato, Hamilton, New Zealand.
}

Copyright 2003 by the American Geophysical Union. 0148-0227/03/2001JB001708\$09.00 and Axen, 1988]. The Wasatch fault is located on the west side of the range and constitutes a major boundary between the relatively stable Colorado Plateau/Rocky Mountain province to the east and the active Basin and Range province to the west. Understanding the timing, rates, and distribution of extension-related exhumation may provide constraints on the mechanism(s) of extensional tectonics in the Basin and Range and in other extensional regions around the world.

[3] The primary goal of this paper is to investigate the longer term (late Cenozoic) timing and style of uplift and exhumation of the central Wasatch Mountains using a relatively dense array of fission track and apatite (U-Th)/He age data. Multiple low-temperature thermochronometer systems are used to provide constraints on the cooling and exhumation history of the rocks in the upper few km of Earth's crust. We focus on the Cottonwood Intrusive Belt (CIB) of the central Wasatch Mountains in the area of the Cottonwood canyons (Figure 2) where, in previous fission track studies 


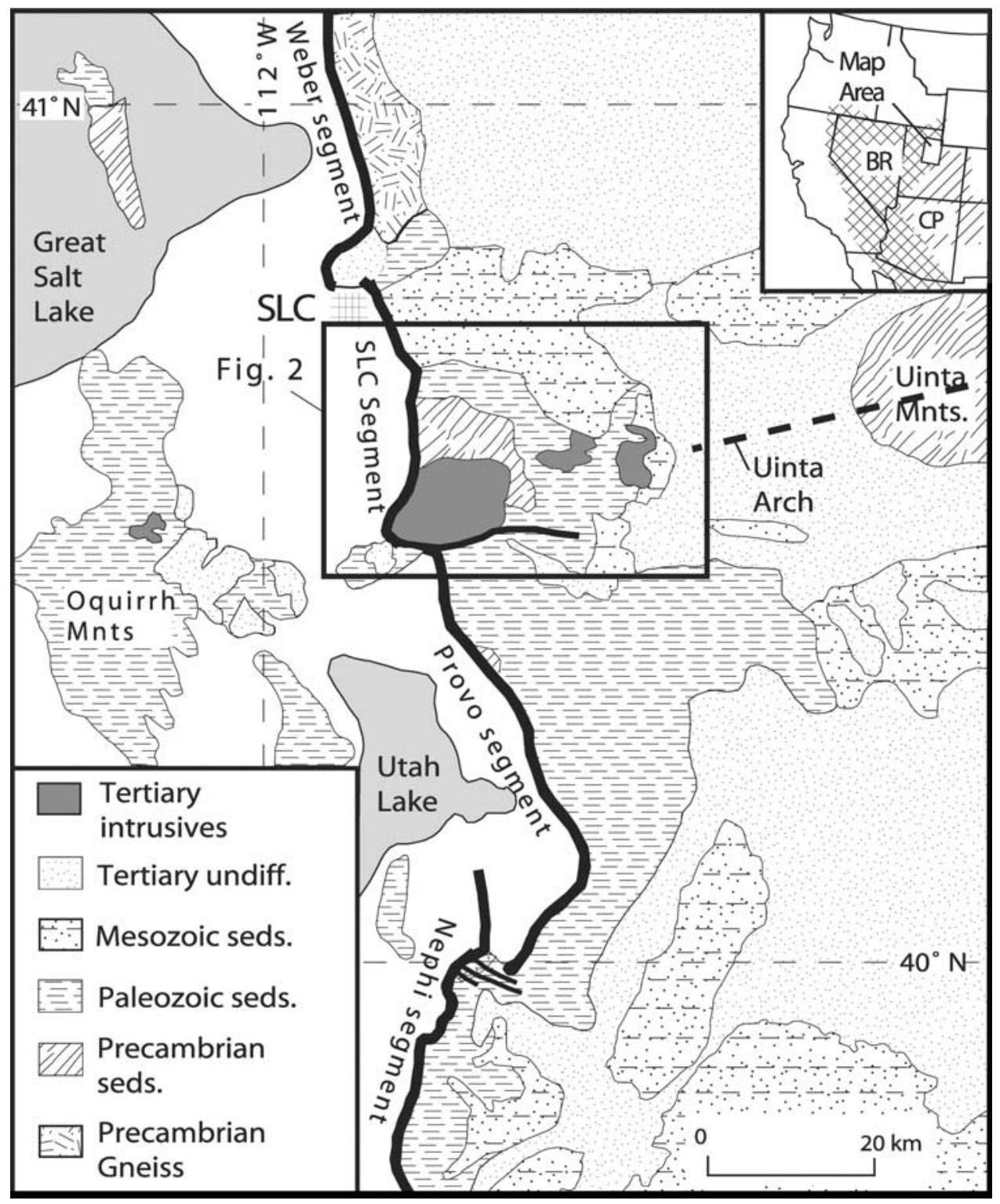

Figure 1. Location and generalized geologic map for the Wasatch Mountains of north central Utah. The Wasatch fault, with segment names, is shown by the bold line. Western United States inset illustrates position of the Wasatch front separating the Basin and Range (BR) province from the Colorado Plateau (CP). SLC is Salt Lake City.

[Evans et al., 1985; Kowallis et al., 1990], samples were collected along a $7 \mathrm{~km}$ transect from the valley floor to the range crest with over $1.9 \mathrm{~km}$ of relief. Data from these studies led the authors to propose exhumation rates of $0.2-0.8 \mathrm{~mm}$ $\mathrm{yr}^{-1}$ for the past $10 \mathrm{Myr}$, which is the same as the timeaveraged exhumation rate for the past $17 \mathrm{Myr}$ deduced from fluid inclusion and radiometric age data from hydrothermally altered footwall rocks in the same area [Parry and Bruhn, 1986, 1987]. Another apatite fission track study of Archean rocks from farther north along the Weber segment of the Wasatch fault [Naeser et al., 1983] showed exhumation rates of $0.4 \mathrm{~mm} \mathrm{yr}^{-1}$. The exhumation rates for the Cottonwood Canyons area are consistent with eastward tilt (west-side-up tilting) of the range about an axis located about $35-40 \mathrm{~km}$ east of the range front. The tilt causes differential exhumation across the range, but the earlier data provide little information on the spatial variations and timing of the range-wide differential exhumation.

[4] In this paper, we present new fission track and apatite (U-Th)/He data that spatially overlap with and extend previous studies. However, our study is based on (1) combined analysis of three thermochronologic data sets and (2) data that span the width and relief of the central Wasatch CIB area. In a related paper [Ehlers et al., 2003], 2-D thermokinematic models and the data presented here are used to infer spatial and temporal variations in exhumation rates and duration of faulting. Using multiple lowtemperature thermochronometers that span the width of the Wasatch Mountains in combination with thermokinematic models, we can better constrain the timing, rate, and overall 
A)

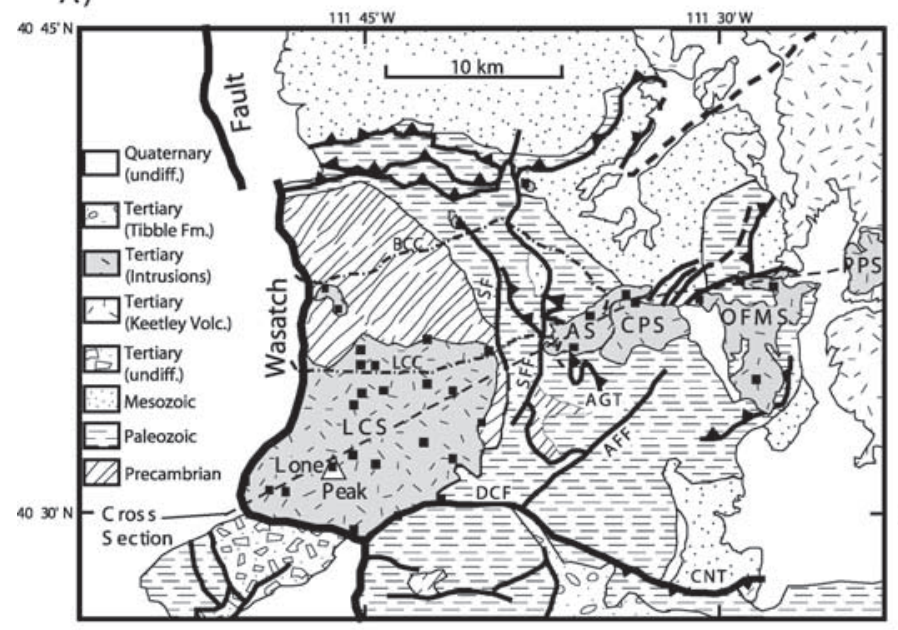

B)

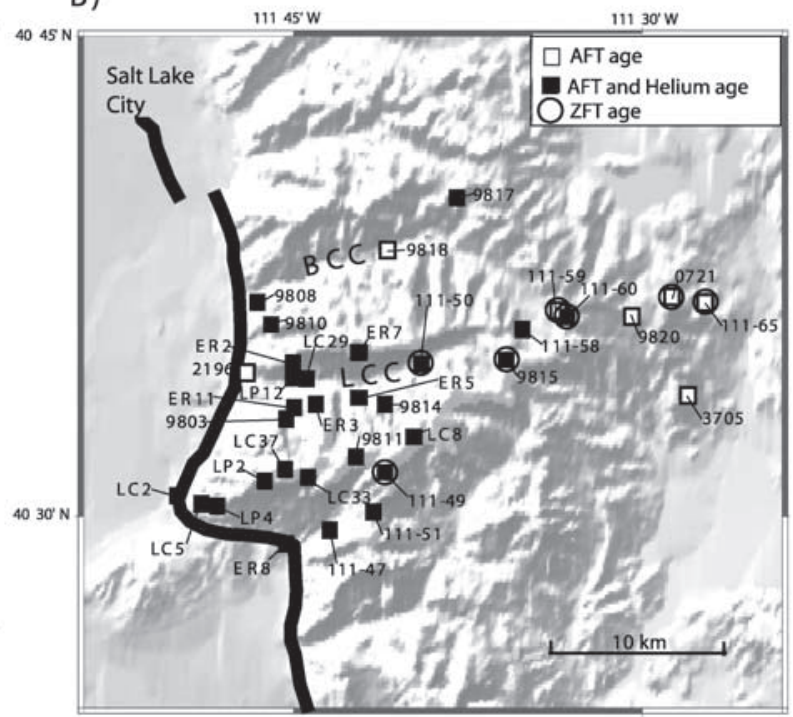

C)

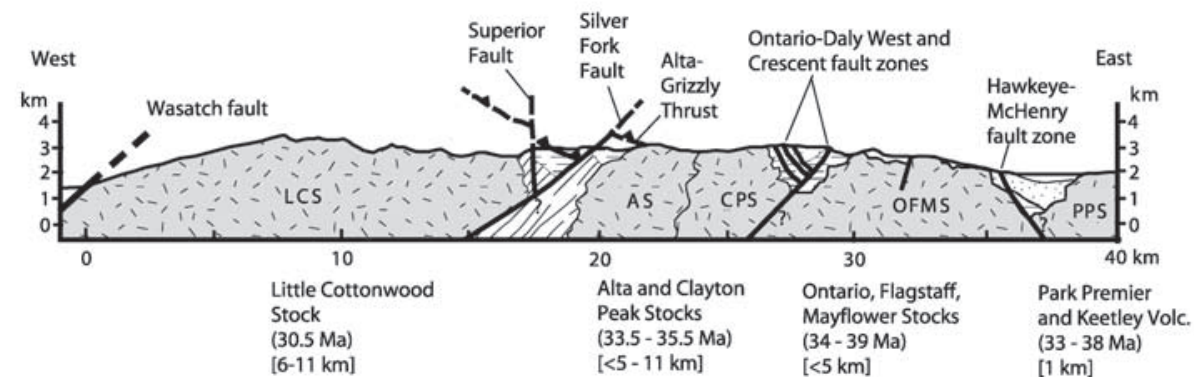

Figure 2. (a) Generalized geologic map, (b) sample location map, and (c) cross section for the central Wasatch region. Geology is generalized from Bryant [1990, 1992]. In Figure 2b, sample numbers are keyed to Tables 1 and 2. In Figure 2c, numbers in parentheses and brackets are intrusion age and depth ranges [John, 1989; Feher et al., 1996; Vogel et al., 1997; Constenius, 1998]. LCC, Little Cottonwood Canyon; BCC, Big Cottonwood Canyon; LCS, Little Cottonwood Stock; AS, Alta Stock; CPS, Clayton Peak Stock; OFMS, Ontario, Flagstaff, and Mayflower stocks; PPS, Park Premier stock; SF, Superior Fault; SFF, Silver Fork Fault; AGT, Alta-Grizzly Thrust; AFF, American Fork Fault; DCF, Deer Creek Fault; CNT, Charleston-Nebo Thrust.

style of late Cenozoic extension-related exhumation of the central Wasatch Mountains.

\section{Geologic Background}

[5] Quaternary fault scarps and geologic mapping of the Wasatch fault suggest that it is an active normal fault system composed of at least six fault segments [Schwartz and Coppersmith, 1984; Machette et al., 1991] (Figure 1). The Wasatch fault is the longest fault in the southern Intermountain Seismic Belt and has generated at least 10 surfacerupturing $(6.8<M<7.3)$ earthquakes in the last 5600 years [McCalpin and Nishenko, 1996]. Late Quaternary fault slip rates for Wasatch segments range from 0.35 to $2.0 \mathrm{~mm} \mathrm{yr}^{-1}$ [McCalpin and Nishenko, 1996].

[6] The study area is limited to the region adjacent to the south end of the Salt Lake segment (Figure 1) where the range is the widest. This part of the range has $2 \mathrm{~km}$ of topographic relief with deeply incised canyons that have been eroded by Pleistocene glaciation.

[7] Several intrusions are located in the central part of the range (Figure 1) in line with the Uinta Arch to the east and a porphyry stock in the Oquirrh Mountains $\sim 30 \mathrm{~km}$ to the west (Figure 1). These intrusions, collectively called the Cottonwood Intrusive Belt (CIB), were emplaced into Precambrian metasediments, Paleozoic miogeoclinal shelf sedimentary rocks, and Mesozoic shelf and terrestrial deposits. The western intrusions (Little Cottonwood, Alta, and Clayton Peak) are phaneritic with granite to granodiorite compositions. Zircon $\mathrm{U} / \mathrm{Pb}$ ages for the intrusions range from $36 \mathrm{Ma}$ for the Clayton Peak stock to $30 \mathrm{Ma}$ for the western Little Cottonwood stock [Feher et al., 1996; Constenius, 1998]. The easternmost intrusions are porphyritic with microcrystalline to fine-grained groundmass and include the Flagstaff, Ontario, Mayflower, and Pine Creek stocks, which range in age from $\sim 34$ to $\sim 39$ Ma [Vogel et al., 1997; Constenius, 1998, and references therein]. The Keetley Volcanics crop out east of the easternmost intrusions dated in this study. They were extruded contemporaneous with the intrusion of the eastern stocks [Bromfield et al., 1977; John, 1989] and locally dip $15-25^{\circ} \mathrm{E}$ [Bryant, 1990]. Volcanism likely continued to at least $28 \mathrm{Ma}$ as documented by $28 \mathrm{Ma}$ volcaniclastic rocks that overlie the Tibble Formation [Constenius, 1998] just south of the CIB. 


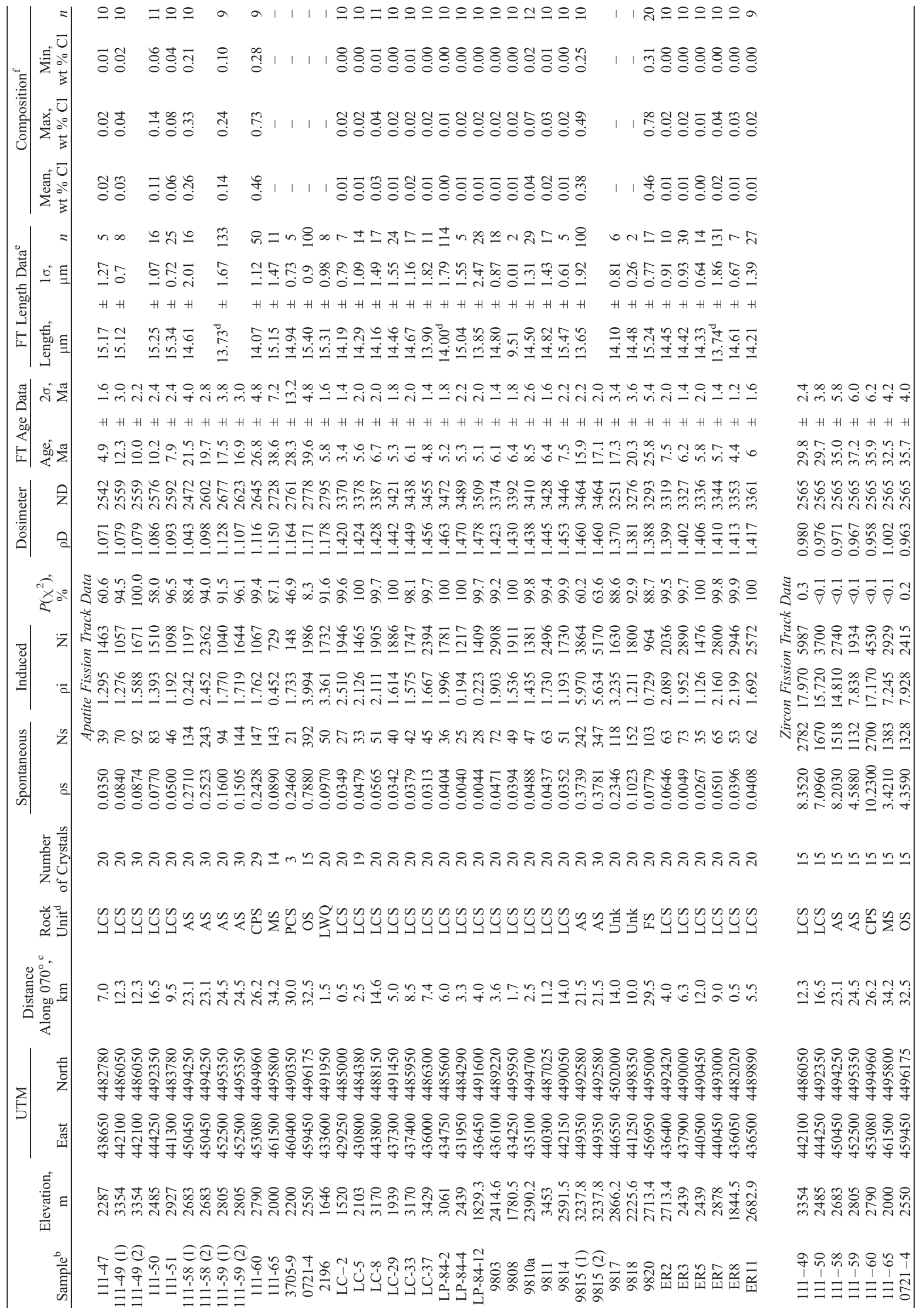


The southern boundary of the intrusive complex is truncated by the Wasatch fault where it strikes E-W at the boundary between the Salt Lake and Provo segments. This Holocene segment boundary appears to extend eastward as the Deer Creek Fault (Figure 2).

[8] Fluid inclusion data, stratigraphic reconstruction, and metamorphic mineral assemblages show that intrusion emplacement depths in the central Wasatch ranged from $\sim 6-11 \mathrm{~km}$ in the west to $<5 \mathrm{~km}$ in the east [John, 1989]. The implication is that the central Wasatch Mountains tilted east about $15-20^{\circ}$ since the Oligocene causing as much as $11 \mathrm{~km}$ of differential exhumation across a distance of $\sim 40$ $\mathrm{km}$ and tilting of the Keetley Volcanics. These results are consistent with fluid inclusion and radiometric age data from hydrothermally altered footwall rocks that suggest a minimum of $11 \mathrm{~km}$ of vertical offset at the range front beginning about 17 Ma [Parry and Bruhn, 1986, 1987]. However, it is unclear whether or not one simple tilt event was responsible for the exhumation of the intrusive complex, or if more than one event with changes in the locus of exhumation through time was responsible.

[9] In addition to the range-bounding Wasatch fault, one other prominent north-south striking fault zone is present. This fault zone consists of the Silver Fork fault (Figure 2), a west-side-down normal fault with $\sim 1500 \mathrm{~m}$ of stratigraphic separation, and the Superior fault located $\sim 3 \mathrm{~km}$ farther west, an east-side-down normal fault with $\sim 800 \mathrm{~m}$ of stratigraphic separation [Crittenden, 1965] (Figure 2). These faults are located between the eastern end of the Little Cottonwood stock and the western end of the Alta stock and bound a region of extensive deformation [Crittenden, 1965]. The Silver Fork-Superior fault system offsets the Alta Stock and Sevier age thrusts and it was active in the late Tertiary.

\section{Fission Track and (U-Th/He) Principles and Methods}

[10] We use the complementary low-temperature thermochronometry techniques of apatite fission track (AFT), zircon fission track (ZFT), and apatite (U-Th)/He dating. The combined use of these methods is emerging as a powerful tool in constraining unroofing histories [e.g., Axen et al., 2000; Blythe et al., 2000; Stockli et al., 2000].

\subsection{Fission Track Analysis}

[11] Fission tracks are damage zones (tracks) of nearly constant length produced from the spontaneous fission of ${ }^{238} \mathrm{U}$. For heating duration of $>1 \mathrm{Myr}$ and typical apatite composition, tracks in apatite anneal (are erased) rapidly to give zero fission track age at temperatures above 110$125^{\circ} \mathrm{C}$. Between $\sim 110$ and $\sim 50^{\circ} \mathrm{C}$, tracks are partially annealed (shortened). The region in the crust that coincides with this temperature range is termed the partial annealing zone (PAZ). At temperatures below $\sim 50^{\circ} \mathrm{C}$, tracks are mostly retained at their initial lengths [e.g., Laslett et al., 1987; Green et al., 1989; Dumitru, 2000].

[12] The systematics of fission track annealing for zircon are not as well constrained as they are for apatite. However, it is well known that zircon fission tracks anneal at higher temperatures than in apatite. Some workers estimate the temperature range for the zircon $\mathrm{PAZ}$ to be between $\sim 210^{\circ} \mathrm{C}$ (no annealing) and $\sim 310^{\circ} \mathrm{C}$ (complete annealing) at heating times of $10^{7}$ years [Yamada et al., 1995; Tagami and Shimada, 1996; Tagami et al., 1998]. Brandon et al. [1998] considered the temperature limits of the PAZ for radiation damaged zircons to be lower at $\sim 180$ to $240^{\circ} \mathrm{C}$ for $10^{7}$ year heating times.

\section{2. (U-Th)/He Analysis}

[13] (U-Th)/He dating relies on the diffusion and retention of ${ }^{4} \mathrm{He}$ produced by radioactive decay of ${ }^{235} \mathrm{U},{ }^{238} \mathrm{U}$, and ${ }^{232} \mathrm{Th}$. Evaluation of diffusion parameters and calibration of ages have been documented by several recent studies [Zeitler et al., 1987; Lippolt et al., 1994; Wolf et al., 1996, 1998; Warnock et al., 1997; Farley, 2000], and the technique has been used to constrain the low-temperature cooling history of rocks [e.g., House et al., 1997; Wolf et al., 1997; Spotila et al., 1998]. Helium is partially retained at temperatures between $40^{\circ} \mathrm{C}$ and $85^{\circ} \mathrm{C}$ in apatite [Wolf et al., 1998]. The depth range that corresponds to this temperature range is termed the partial retention zone (PRZ). At temperatures below $40^{\circ} \mathrm{C}$ most helium is retained in the apatite crystal, and above $85^{\circ} \mathrm{C}$ most helium is lost. Diffusion experiments for typical size grains (radius of $60 \pm 20 \mu \mathrm{m}$ ) of Durango apatite show that the best estimate of closure temperature is $65^{\circ} \mathrm{C}$ at cooling rates of $10^{\circ} \mathrm{C} \mathrm{Myr}^{-1}$ [Farley, 2000].

\section{Sampling Strategy and Age Dating Procedures}

[14] Sampling was confined to the central Wasatch CIB and spans a region $\sim 35 \mathrm{~km}(\mathrm{E}-\mathrm{W})$ by $\sim 20 \mathrm{~km}(\mathrm{~N}-\mathrm{S})$ (Figure 2). We collected 26 samples and utilized separates from nine samples collected for the Kowallis et al. [1990] and Evans et al. [1985] studies.

[15] Fission track ages were determined on 35 apatite and 7 zircon separates (Table 1). All samples (except sample 2196) are from Oligocene plutonic rocks of central Wasatch. The ages and track length distributions were measured in

\footnotetext{
Notes to Table 1

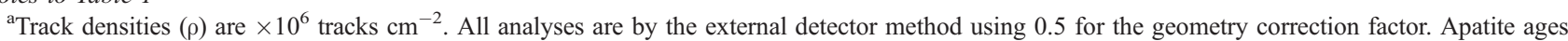
calculated using dosimeter glass SRM 612 and zeta- $612=343.5 \pm 4.5( \pm 1 \sigma)$. Zircon ages are calculated using dosimeter glass CN-1 and zeta-CN-1 $=135.6$ $\pm 1.2( \pm 1 \sigma)$. Age standards include Fish Canyon Tuff, Durango, and Mount Dromedary. $P\left(\chi^{2}\right)$ is the probability of obtaining $\chi^{2}$ value for $v$ degrees of freedom (where $v$ is the number of crystals -1 ) [Galbraith, 1981]; pooled $\rho$ s/ $\rho$ i ratio is used to calculate age and uncertainty where $P\left(\chi^{2}\right)>5 \%$; mean $\rho$ s/ $\rho$ i ratio is used for samples where $P\left(\chi^{2}\right)<5 \%$ and for which central ages [Galbraith and Laslett, 1993] are calculated. Apatite grain mounts were etched in 5 $\mathrm{M} \mathrm{HNO}_{3}$ for $20 \mathrm{~s}$ at $21^{\circ} \mathrm{C}$. Teflon zircon grain mounts were etched in $\mathrm{NaOH}: \mathrm{KOH}$ eutectic solution at $230 \pm 1^{\circ} \mathrm{C}$ for $\sim 30$ hours.

${ }^{b}$ LC and LP samples are replicates from Kowallis et al. [1990] and Evans et al. [1985]. Number in parentheses is replicate number for samples that were dated more than once.

${ }^{\mathrm{c}}$ Distance measured along an azimuth of $070^{\circ}$ from surface expression of Wasatch fault.

${ }^{\mathrm{d}}$ LCS, Little Cottonwood Stock; AS, Alta Stock; CPS, Clayton Peak Stock; unk, unnamed exposures but probably associated with the Alta and Clayton Peak stocks; FS, Flagstaff Stock; OS, Ontario Stock; MS, Mayflower Stock; PCS, Pine Creek Stock; LWQ, Little Willow Quartzite.

${ }^{\mathrm{e}}$ Track length distribution contains Cf-252 derived track lengths [Donelick and Miller, 1991]. Numbers of Cf-252 tracks are 90,98 , and 69 for samples ER7, 111-59, and LP84-2, respectively.

${ }^{\mathrm{f}}$ Apatite composition measured using Cameca SX-50 electron microprobe.
} 
Table 2. (U-Th)/He Age Data

\begin{tabular}{|c|c|c|c|c|c|c|c|c|c|c|c|}
\hline \multirow[b]{2}{*}{ Sample $^{\mathrm{a}}$} & \multirow{2}{*}{$\begin{array}{c}\text { Elevation, } \\
\mathrm{m}\end{array}$} & \multicolumn{2}{|c|}{ UTM } & \multirow{2}{*}{$\begin{array}{c}\text { Distance } \\
\text { Along } 070^{\circ},{ }^{\mathrm{b}} \mathrm{km} \\
\end{array}$} & \multirow{2}{*}{$\begin{array}{c}\mathrm{U}, \\
\mathrm{ppm}\end{array}$} & \multirow{2}{*}{$\begin{array}{l}\text { Th, } \\
\text { ppm }\end{array}$} & \multirow{2}{*}{$\begin{array}{c}\mathrm{He}, \\
\mathrm{nmolg}^{-1} \\
\end{array}$} & \multirow[b]{2}{*}{$\mathrm{Ft}^{\mathrm{c}}$} & \multirow{2}{*}{$\begin{array}{l}\text { Ft Corrected } \\
\text { He Age, Ma }\end{array}$} & \multirow{2}{*}{$\begin{array}{c}\text { Average He } \\
\text { Age, }{ }^{\mathrm{d}} \mathrm{Ma}\end{array}$} & \multirow{2}{*}{$\begin{array}{c}\text { Uncertainty, }^{\mathrm{e}} \\
\mathrm{Ma} \\
\end{array}$} \\
\hline & & East & North & & & & & & & & \\
\hline $111-47$ (1) & 2287 & 438650 & 4482780 & 7.0 & 14.3 & 34.7 & 0.341 & 0.67 & 3.3 & 4.2 & 1.7 \\
\hline $111-47$ (2) & 2287 & 438650 & 4482780 & 7.0 & 9.3 & 21.0 & 0.277 & 0.71 & 5.0 & & \\
\hline $111-49$ & 3354 & 442100 & 4486050 & 12.3 & 15.8 & 36.3 & 0.610 & 0.75 & 6.0 & 6.0 & 0.9 \\
\hline $111-50$ & 2485 & 444250 & 4492350 & 16.5 & 17.3 & 26.3 & 0.773 & 0.75 & 6.2 & 6.2 & 0.9 \\
\hline $111-51$ & 2927 & 441300 & 4483780 & 9.5 & 11.8 & 31.5 & 0.368 & 0.74 & 4.6 & 4.6 & 0.7 \\
\hline $111-58$ & 2683 & 450450 & 4494250 & 23.1 & 19.1 & 29.4 & 1.145 & 0.78 & 10.1 & 10.1 & 1.5 \\
\hline $111-60(1)$ & 2790 & 453080 & 4494960 & 24.5 & 18.4 & 50.1 & 2.661 & 0.81 & 19.9 & 23.0 & 2.1 \\
\hline $111-60(2)$ & 2790 & 453080 & 4494960 & 24.5 & 19.9 & 43.0 & 2.572 & 0.65 & 24.2 & & \\
\hline $111-60$ (3) & 2790 & 453080 & 4494960 & 24.5 & 16.3 & 45.5 & 2.281 & 0.78 & 24.6 & & \\
\hline $111-60$ (4) & 2790 & 453080 & 4494960 & 24.5 & 23.4 & 51.6 & 3.370 & 0.75 & 23.2 & & \\
\hline LC-2 & 1520 & 429250 & 4485000 & 0.5 & 12.9 & 24.8 & 0.179 & 0.73 & 1.6 & 1.6 & 0.2 \\
\hline LC-5 & 2103 & 430800 & 4484380 & 2.5 & 13.2 & 25.3 & 0.229 & 0.77 & 2.6 & 2.6 & 0.4 \\
\hline LC-8 (1) & 3170 & 443800 & 4488150 & 14.6 & 14.6 & 36.0 & 0.999 & 0.72 & 10.6 & 9.5 & 2.1 \\
\hline LC-8 (2) & 3170 & 443800 & 4488150 & 14.6 & 14.7 & 38.3 & 0.684 & 0.63 & 8.5 & & \\
\hline LC-29 & 1939 & 437300 & 4491450 & 5.0 & 9.9 & 23.7 & 0.295 & 0.79 & 3.8 & 3.8 & 0.6 \\
\hline LC-33 & 3170 & 437400 & 4485950 & 8.5 & 9.8 & 22.3 & 0.259 & 0.78 & 3.9 & 3.9 & 0.6 \\
\hline LC-37 (1) & 3429 & 436000 & 4486300 & 7.4 & 11.4 & 25.7 & 0.409 & 0.77 & 4.9 & 5.0 & 0.2 \\
\hline LC-37 (2) & 3429 & 436000 & 4486300 & 7.4 & 8.5 & 20.7 & 0.284 & 0.77 & 5.1 & & \\
\hline LP-84-2 & 3061 & 434750 & 4485600 & 6.0 & 12.5 & 29.1 & 0.299 & 0.78 & 3.5 & 3.5 & 0.5 \\
\hline LP-84-4 (1) & 2439 & 431950 & 4484290 & 3.3 & 16.1 & 34.8 & 0.299 & 0.69 & 2.7 & 2.7 & 0.1 \\
\hline LP-84-4 (2) & 2439 & 431950 & 4484290 & 3.3 & 12.6 & 27.8 & 0.186 & 0.66 & 2.7 & & \\
\hline LP-84-12 (1) & 1829.3 & 436450 & 4491600 & 4.0 & 16.7 & 35.6 & 0.322 & 0.66 & 2.9 & 3.2 & 0.4 \\
\hline LP-84-12 (2) & 1829.3 & 436450 & 4491600 & 4.0 & 13.7 & 28.3 & 0.259 & 0.69 & 3.4 & & \\
\hline 9803 & 2414.6 & 436100 & 4489220 & 3.6 & 10.0 & 23.8 & 0.274 & 0.84 & 3.8 & 3.8 & 0.6 \\
\hline 9808 (1) & 1780.5 & 434250 & 4495950 & 1.7 & 7.4 & 9.0 & 0.217 & 0.78 & 5.3 & 6.2 & 1.9 \\
\hline 9808 (2) & 1780.5 & 434250 & 4495950 & 1.7 & 6.9 & 7.5 & 0.256 & 0.76 & 7.2 & & \\
\hline 9810a (1) & 2390.2 & 435100 & 4494700 & 2.5 & 10.8 & 25.2 & 0.317 & 0.74 & 4.2 & 4.7 & 0.9 \\
\hline 9810a (2) & 2390.2 & 435100 & 4494700 & 2.5 & 9.8 & 23.9 & 0.320 & 0.75 & 5.1 & & \\
\hline 9811 & 3453 & 440300 & 4487025 & 11.2 & 7.9 & 20.9 & 0.317 & 0.80 & 5.5 & 5.5 & 0.8 \\
\hline 9814 & 2591.5 & 442150 & 4490050 & 14.0 & 5.5 & 13.2 & 0.313 & 0.81 & 7.9 & 7.9 & 1.2 \\
\hline 9815 (1) & 3237.8 & 449350 & 4492580 & 21.5 & 31.8 & 52.3 & 1.736 & 0.78 & 9.2 & 9.4 & 0.5 \\
\hline 9815 (2) & 3237.8 & 449350 & 4492580 & 21.5 & 30.0 & 51.2 & 1.675 & 0.76 & 9.7 & & \\
\hline 9817 & 2866.2 & 446550 & 4502000 & 14.0 & 14.5 & 27.7 & 0.585 & 0.76 & 6.1 & 6.1 & 0.9 \\
\hline ER2 & 2713.4 & 436400 & 4492420 & 4.0 & 11.6 & 27.0 & 0.442 & 0.79 & 5.7 & 5.7 & 0.8 \\
\hline ER3 (1) & 2439 & 437900 & 4490000 & 6.3 & 14.9 & 21.7 & 0.432 & 0.84 & 4.7 & 4.6 & 0.1 \\
\hline ER3 (2) & 2439 & 437900 & 4490000 & 6.3 & 13.8 & 19.5 & 0.329 & 0.72 & 4.6 & & \\
\hline ER5 & 2439 & 440500 & 4490450 & 12.0 & 6.3 & 15.5 & 0.205 & 0.71 & 4.9 & 4.9 & 0.7 \\
\hline ER7 & 2878 & 440450 & 4493000 & 9.0 & 6.6 & 14.0 & 0.265 & 0.78 & 6.3 & 6.3 & 0.9 \\
\hline ER8 & 1844.5 & 436050 & 4482020 & 0.5 & 12.1 & 27.8 & 0.299 & 0.79 & 3.6 & 3.6 & 0.5 \\
\hline ER11 & 2682.9 & 436500 & 4489890 & 5.5 & 10.2 & 24.0 & 0.294 & 0.82 & 4.1 & 4.1 & 0.6 \\
\hline
\end{tabular}

${ }^{a}$ Number in parentheses is replicate number where more than one analysis on same sample. For sample 111-60, replicates (3) and (4) are single-grain laser ages [House et al., 2000].

${ }^{\mathrm{b}}$ Distance along azimuth of $070^{\circ}$ from present exposure of Wasatch fault to sample location.

${ }^{c} \mathrm{Ft}$ is alpha-stopping distance correction factor [Farley et al., 1996].

${ }^{\mathrm{d}}$ Average age where more than one replicates, age is the average of replicate ages.

${ }^{\text {e }}$ Standard error of the mean at $2 \sigma$ for samples with more than one analysis; $15 \%$ for samples with one analysis (see text).

the Geochronology Lab at the University of Waikato using the external detector method. To assess the repeatability of the apatite fission track ages, four samples were measured twice (Table 1); ages were replicated well within the individual age uncertainties.

[16] Apatite (U-Th)/He ages were determined for 28 separates from the 35 apatite fission track samples. For each sample, 8 to 15 grains were dated. These grains were visually inspected under cross-polar transmitted light to eliminate grains with potential high-uranium phase (such as zircon) inclusions and other potential impurities. Grain dimensions were measured on a calibrated stage at $110 \times$ to determine the $\alpha$ emission correction [Farley et al., 1996]. The euhedral apatite crystals had average widths of $\sim 70$ $100 \mu \mathrm{m}$ and lengths of $180-280 \mu \mathrm{m}$. Thermally outgassed helium was measured for ${ }^{4} \mathrm{He} /{ }^{3} \mathrm{He}$ ratios on a quadrapole mass spectrometer, followed by evaluation of $U$ and $T h$ (in solution after dissolving outgassed grains) on an ICPMS. Analytical uncertainties were generally better than $3 \%(1 \sigma)$.
[17] In order to assess the repeatability of the (U-Th)/He ages, we ran one replicate each on nine different samples (Table 2). Two separate single-grain laser ages [House et al., 2000] were determined on one of the samples (111-60, Table 2). The laser ages show good repeatability with the furnace ages. The average uncertainty in the furnace age samples is $\sim 10.5 \%(1 \sigma)$ and the average relative standard error of the mean at two standard deviations is $15 \%$, where the relative standard error of the mean for any replicated sample is $[100 \times 2 \sigma] /[t \sqrt{ } N]$ ( $\sigma$ is the standard deviation, $t$ is average age of sample, and $N$ is number of age analyses). Thus we adopt a conservative uncertainty of $\pm 15 \%$ (at $2 \sigma$ ) for the nonreplicated samples (Table 2).

\section{Results}

\subsection{Apatite Fission Track Data}

[18] The AFT ages range from 3.4 to $39.6 \mathrm{Ma}$ (Table 1 and Figure 3 ) and display an overall increase in age to the 


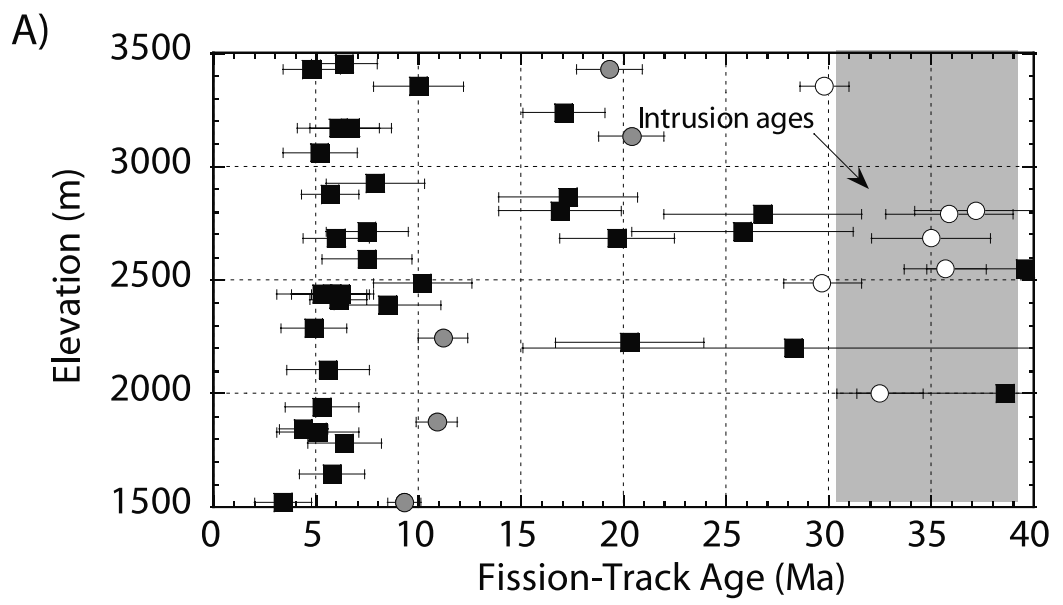

B)

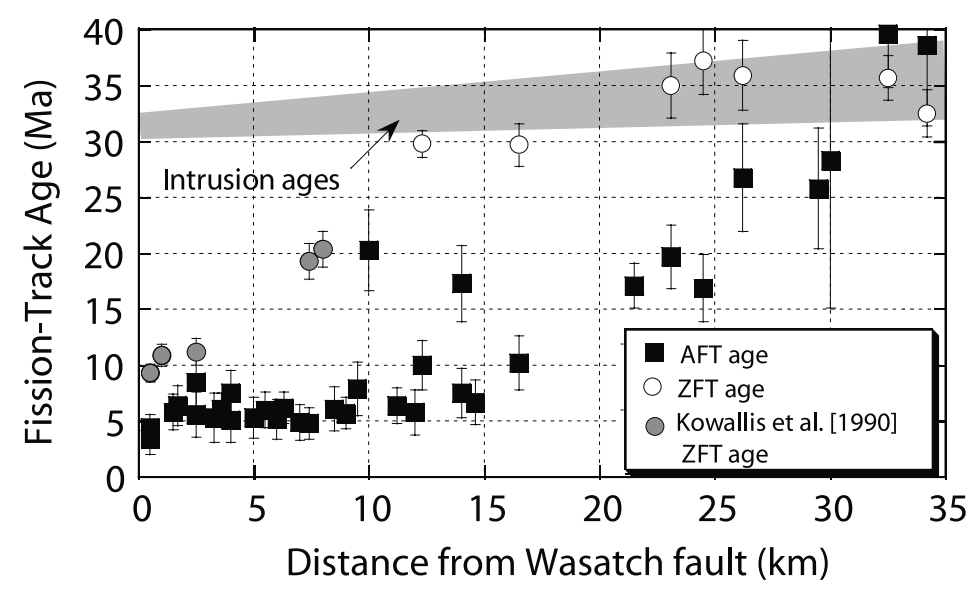

Figure 3. Apatite and zircon fission track data versus (a) elevation and (b) distance from Wasatch fault. In Figure $3 b$, distance is measured from Wasatch fault along a trend of $070^{\circ}$ to correspond to the cross section in Figure 2. Kowallis ZFT ages are from Kowallis et al. [1990]. AFT, apatite fission track; ZFT, zircon fission track. Intrusion ages references are same as in Figure 2.

east (Figure 4). All but two of the AFT ages are younger than the $\mathrm{U} / \mathrm{Pb}$ emplacement ages of the intrusion, with the two oldest ages being essentially the same age as the easternmost intrusions (Figure 3). Single grain age distributions for most of the AFT samples are narrow, resulting in $P\left(\chi^{2}\right)$ [Galbraith, 1981] values typically $>80 \%$. Low values of $P\left(\chi^{2}\right)$ indicate large grain age dispersion caused by mixing of detrital grains, significant time in the apatite partial annealing zone, sample reheating, and/or variations in apatite chemistry.

[19] LC and LP samples (Table 1) are replicates of age determinations published by Kowallis et al. [1990] and Evans et al. [1985], respectively. Our new ages are somewhat younger, but error bars generally overlap at the $2 \sigma$ level. Ages from the earlier studies were determined using the population method [Naeser et al., 1989] and zero age grains may not have been included in the age determination.

[20] AFT ages less than $8 \mathrm{Ma}$ show an age increase with increasing elevation (Figure 3a), which is typical of elevation versus age profiles in many mountain belts. However, AFT ages that are $>8 \mathrm{Ma}$ continue to increase as elevation decreases. Thus there is no clear range-wide systematic increase in AFT age with elevation. AFT ages increase from $5 \mathrm{Ma}$ at the Wasatch fault to about $10 \mathrm{Ma}$ at $15 \mathrm{~km}$ east of the fault (Figure 3b). The exceptions are samples 9817 and
9818, which are located north of the main sample region. The ages increase to $15-26 \mathrm{Ma}$ cross the region outlined by the Superior and Silver Fork faults at 17-25 km (Figure $3 \mathrm{~b})$. Ages increase to the age of the easternmost intrusions (30-38 Ma) at distances greater than $25 \mathrm{~km}$ east.

[21] Fission track length data were collected where possible, but for many samples the track density is low (Table 1); ideally, 100+ horizontal, confined tracks should be measured per sample. The low numbers of tracks for our samples are typical for very young age samples. In order to augment the track length distributions in some samples we used a Cf-252 source to reveal more horizontal, confined tracks [Donelick and Miller, 1991]. For these samples, the Cf-252 enhanced track lengths were combined with those from the non-Cf-252 track lengths (Table 1). The mean lengths are long (13.7$15.3 \mu \mathrm{m})$, indicating relatively rapid cooling through the apatite PAZ.

[22] AFT annealing depends partially on the chlorine content of the apatite. High chlorine content in apatite decreases the amount of annealing [Green et al., 1989] and leads to older apparent AFT ages relative to apatites with low chlorine contents. We analyzed representative sample aliquots from four intrusions (Little Cottonwood, Alta, Clayton Peak, and Flagstaff) by electron microprobe. Apatites from the Alta, Clayton Peak, and Flagstaff stocks average 0.30- 

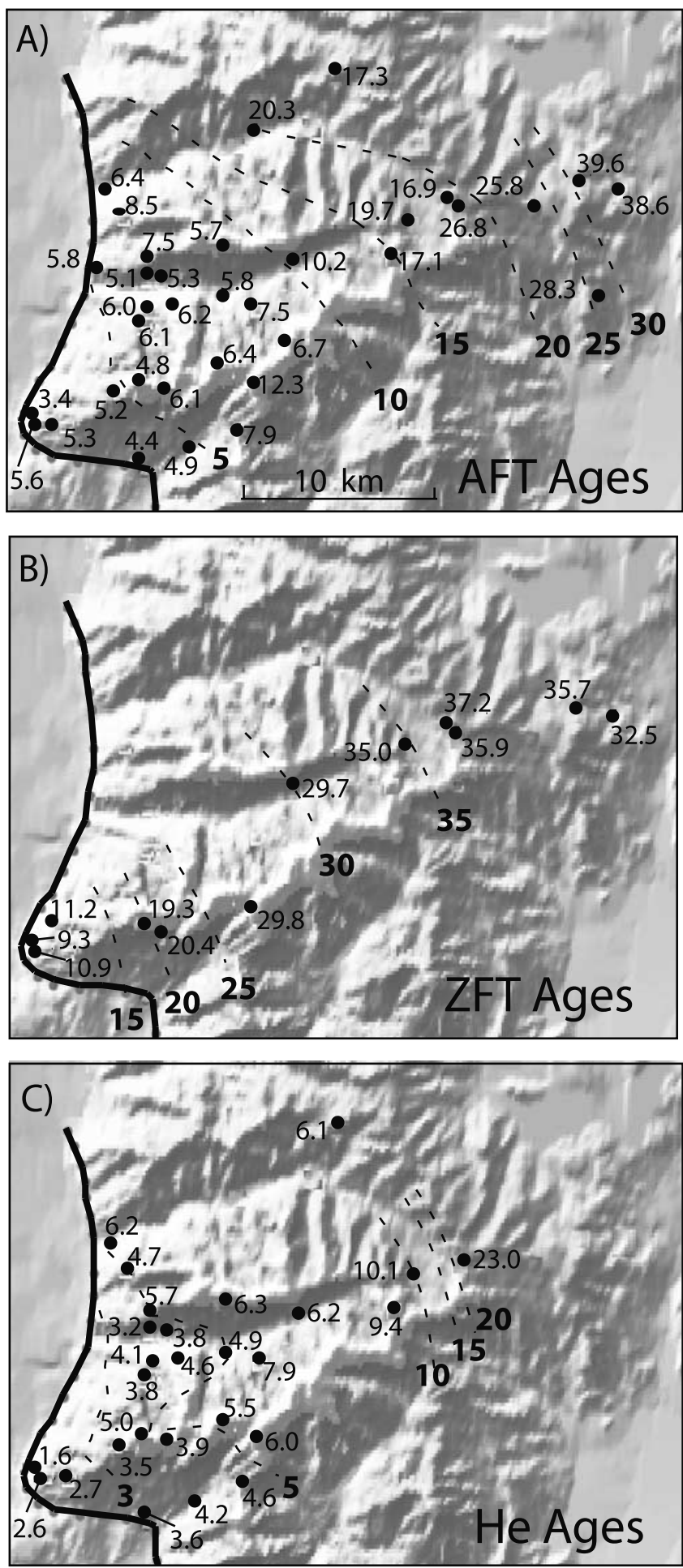

Figure 4. Maps of (a) apatite fission track, (b) zircon fission track, and (c) apatite (U-Th)/He ages. Contours are generalized. Contour labels and sample ages are in Ma.

0.45 wt $\% \mathrm{Cl}$, whereas those from the Little Cottonwood stock have values of $0.1 \mathrm{wt} \% \mathrm{Cl}$ or less (Table 1 ).

\subsection{Zircon Fission Track Data}

[23] Our new ZFT ages range from 30 to $37 \mathrm{Ma}$ (Table 1 and Figure 3), with the youngest from the westernmost samples (Table 1). Kowallis et al. [1990] report ZFT ages of $10 \mathrm{Ma}$ at the Wasatch fault to $20 \mathrm{Ma}$ at $8 \mathrm{~km}$ east of the fault. Our samples are from farther east and when combined with the Kowallis et al. [1990] data reflect a general increase in age from the range front toward the eastern margin of the range (Figures $3 \mathrm{~b}$ and $4 \mathrm{~b}$ ). ZFT ages are concordant with the intrusion ages at distances greater than $20 \mathrm{~km}$ from the Wasatch fault. $P\left(\chi^{2}\right)$ values are low $(<0.3 \%$; Table 1) with youngest single grain ages in each sample of 22-30 Ma. The low $P\left(\chi^{2}\right)$ values indicate that some of the intrusions may have experienced reheating in the Oligocene, probably associated with volcanism prior to final cooling.

\section{3. (U-Th)/He Data}

[24] (U-Th)/He ages range from 1.6 to $23.0 \mathrm{Ma}$ (Figure 5 and Table 2) and show an overall increase in age with elevation but with considerable scatter (Figure 5a). For example, ages vary by a factor of three $(\sim 3-10 \mathrm{Ma})$ at an elevation of $\sim 2500-2700 \mathrm{~m}$. The $(\mathrm{U}-\mathrm{Th}) / \mathrm{He}$ ages reflect both elevation and spatial position in the range as shown by Figure 5a where the age data are binned in $5 \mathrm{~km}$ increments (east of the Wasatch fault) to evaluate the relationships in age with elevation and distance from the Wasatch fault. Within $10 \mathrm{~km}$ of the fault, ages increase with elevation from about $2 \mathrm{Ma}$ at $1500 \mathrm{~m}$ to about $6 \mathrm{Ma}$ at the highest elevation $(3450 \mathrm{~m})$. There is not a clear age-elevation relation farther into the range (10 to $30 \mathrm{~km})$. However, $(\mathrm{U}-\mathrm{Th}) / \mathrm{He}$ ages do increase farther into the range even where elevation is lower relative to those within $10 \mathrm{~km}$ of the fault (Figures 5a and 5c).

[25] The closure temperature is low enough $\left(\sim 65^{\circ} \mathrm{C}\right)$ for helium in apatite that topographic variations between sample locations may lead to variations in the apparent (U-Th)/He ages [e.g., House et al., 1998; Braun, 2002]. In order to investigate the potential effects of topography and separate them from possible spatial effects related to range tilt, we evaluated a north-south elevation-age profile from Lone Peak to the bottom of Little Cottonwood Canyon that maximizes relief. (U-Th)/He ages along this profile (Figure $5 \mathrm{~b}$ ) presumably would be affected by elevation and exhumation rate at that location, and not by distance into the range. (U$\mathrm{Th}$ )/He ages in this subset increase with elevation at a best fit gradient of $0.8 \mathrm{Myr} \mathrm{km}^{-1}$. If exhumation rates increase from east to west due to eastward tilt, this gradient would be slightly less to the west, and slightly greater to the east, of the $\mathrm{N}-\mathrm{S}$ profile. Figure $5 \mathrm{c}$ shows the (U-Th)/He ages elevationcorrected from their actual elevations to a common elevation of $2500 \mathrm{~m}$ using the above gradient. These elevationcorrected $(\mathrm{U}-\mathrm{Th}) / \mathrm{He}$ ages increase with distance from the Wasatch fault (Figure 5c) indicating that factors other than elevation cause the ages to vary across the range.

[26] Samples located within $25 \mathrm{~km}$ from the Wasatch fault have (U-Th)/He ages that increase nearly linearly with distance to the northeast (Figure 5c). A major change occurs between 23 and $27 \mathrm{~km}$ (Figure 5c) where the easternmost $(\mathrm{U}-\mathrm{Th}) / \mathrm{He}$ age $(23.0 \mathrm{Ma})$ is more than twice that of the other samples. The three oldest samples from within $5 \mathrm{~km}$ of the Wasatch fault (samples 9808, 9810, and ER2, circled in Figure 5c) also lie off the linear increase in age with distance trend. These samples are the northernmost samples along the range front and north of the Little CottonwoodLone Peak drainage system. Their older ages, relative to 
A)

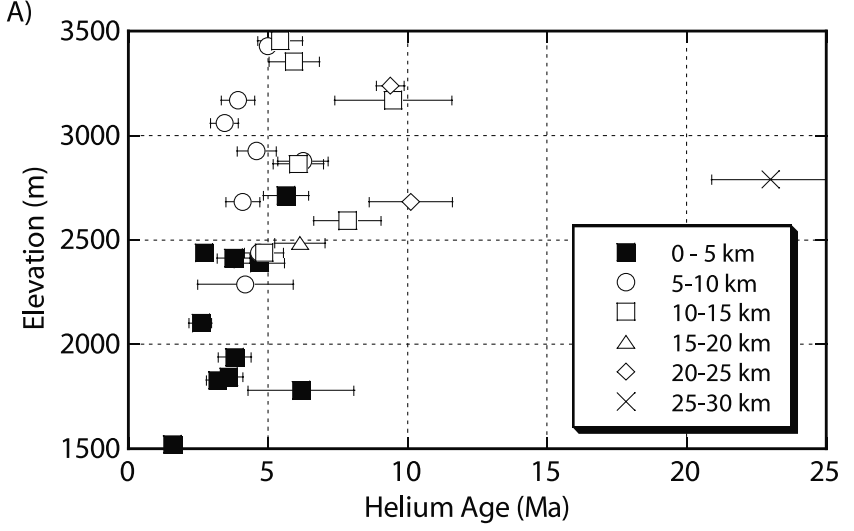

B)

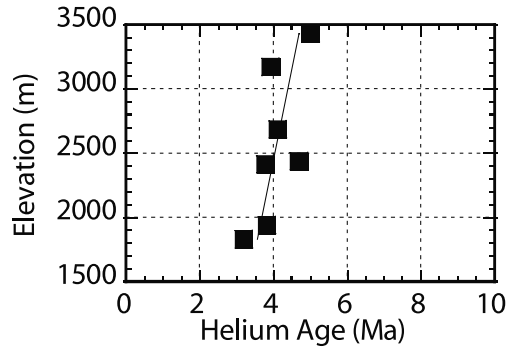

C)

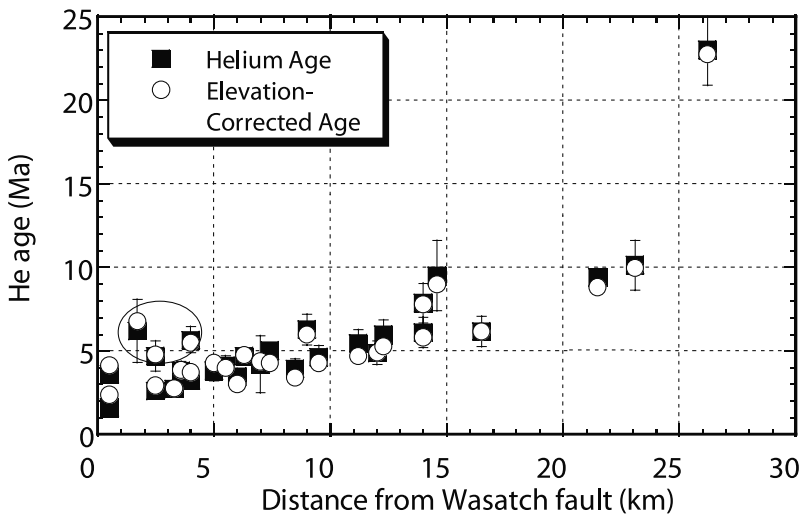

Figure 5. Apatite (U-Th)/He age data versus elevation and distance from Wasatch fault. (a) Data grouped in $5 \mathrm{~km}$ bins east of the Wasatch fault. (b) Samples representing a northsouth elevation versus age profile from Lone Peak to the bottom of Little Cottonwood Canyon that maximizes relief at a common distance from the Wasatch fault. (c) Open circles, (U-Th)/He ages corrected for a common elevation of $2500 \mathrm{~m}$ using the data fit in Figure 5b. Circled samples in Figure 5c (9808, 9810, and ER2) are the northernmost samples adjacent to the Wasatch fault and are well north of the main sampled region.

ages of samples with the same distance from fault farther south, may reflect a component of northward tilt [Armstrong et al., 2000].

\section{Apatite Fission Track and (U-Th)/He Age Modeling}

[27] Representative samples or sample groups were chosen to constrain thermal histories of samples from across the range (Figure 6 and Table 3). Grouping of samples from 3 of the 8 sample regions allows combination of single grain age and track length data where track length single grain age data from individual young age samples are insufficient. Combining data from individual samples could potentially bias the group results due to the averaging of single grain age and track length distributions. However, we argue that grouping the samples leads to better results than attempting to model single samples for which there are even fewer track length data because the 3 to 5 individual samples in each group (Table 3) are within about $300 \mathrm{~m}$ computed paleodepth of one another. Assuming a typical geothermal gradient, this paleodepth distribution limits the temperature difference of these samples during simple cooling histories to less than about $10^{\circ} \mathrm{C}$, which is near the limit of temperature discrimination in the thermal modeling.

[28] The program AFTSolve [Ketcham et al., 2000] was used to model the fission track data. AFTSolve allows a variety of annealing models to be utilized. We used the annealing model of Ketcham et al. [1999], which allows the user to vary kinetic parameters such as chlorine content in each model run. In each of the model simulations, the sample- or group-specific kinetic data $(w t \% \mathrm{Cl})$ were used. For sample 0721, no composition data are available and composition data for nearby sample 9820 were used as a representative proxy. In lieu of initial track length data, the annealing coefficients based on the data of Carlson et al. [1999] were used to control the initial track lengths. Additional simulations using the annealing model of Laslett et al. [1987] gave similar results in terms of acceptable thermal histories. Ten thousand simulations were run using a Monte Carlo search technique; simulations using a constrained random search technique [Willett, 1997] produced similar results. ZFT age constraints were included for all samples or sample groups (Table 3) assuming a temperature range of $210-250^{\circ} \mathrm{C}$ for the lower-temperature limit of the zircon PAZ. In each model run a best fit thermal history was computed, as well as envelopes of statistically "acceptable" thermal histories based on specified merit function values [Ketcham et al., 2000] (Figure 6). (U-Th)/He ages were computed using a spherical finite element model [Ehlers et al., 2001, 2003] for all the acceptable temperature histories from the AFT modeling. The temperature histories that produce acceptable (U-Th)/He ages (within $2 \sigma$ uncertainty) for each sample or sample group further constrain the lowtemperature portion of the temperature histories.

[29] In the descriptions of the modeling results below, the samples are divided into regions based on distance from the Wasatch fault. Figure 7 shows summary thermal histories for the regions where AFT data were modeled.

\subsection{Range Front: 0 to $17 \mathrm{~km}$ from the Wasatch Fault}

[30] Acceptable temperature history results for samples within $17 \mathrm{~km}$ of the fault indicate rapid cooling from greater than $150^{\circ} \mathrm{C}$ to less than $50^{\circ} \mathrm{C}$ between about 10 and $5 \mathrm{Ma}$, depending on distance from the Wasatch fault (Figures 6 and 7). The temperature histories that satisfy the (U-Th)/He ages for each sample corroborate the low temperature portions of the temperature histories. One exception is sample ER7 (Figure 6) where the measured (U-Th)/He age is 6.3 Ma, which is older than the sample's AFT age. This (U-Th)/He age is also old relative to nearby samples (samples 111-51, LC33, LC37, and ER3, Table 2) from the same intrusion and with similar distance and computed 

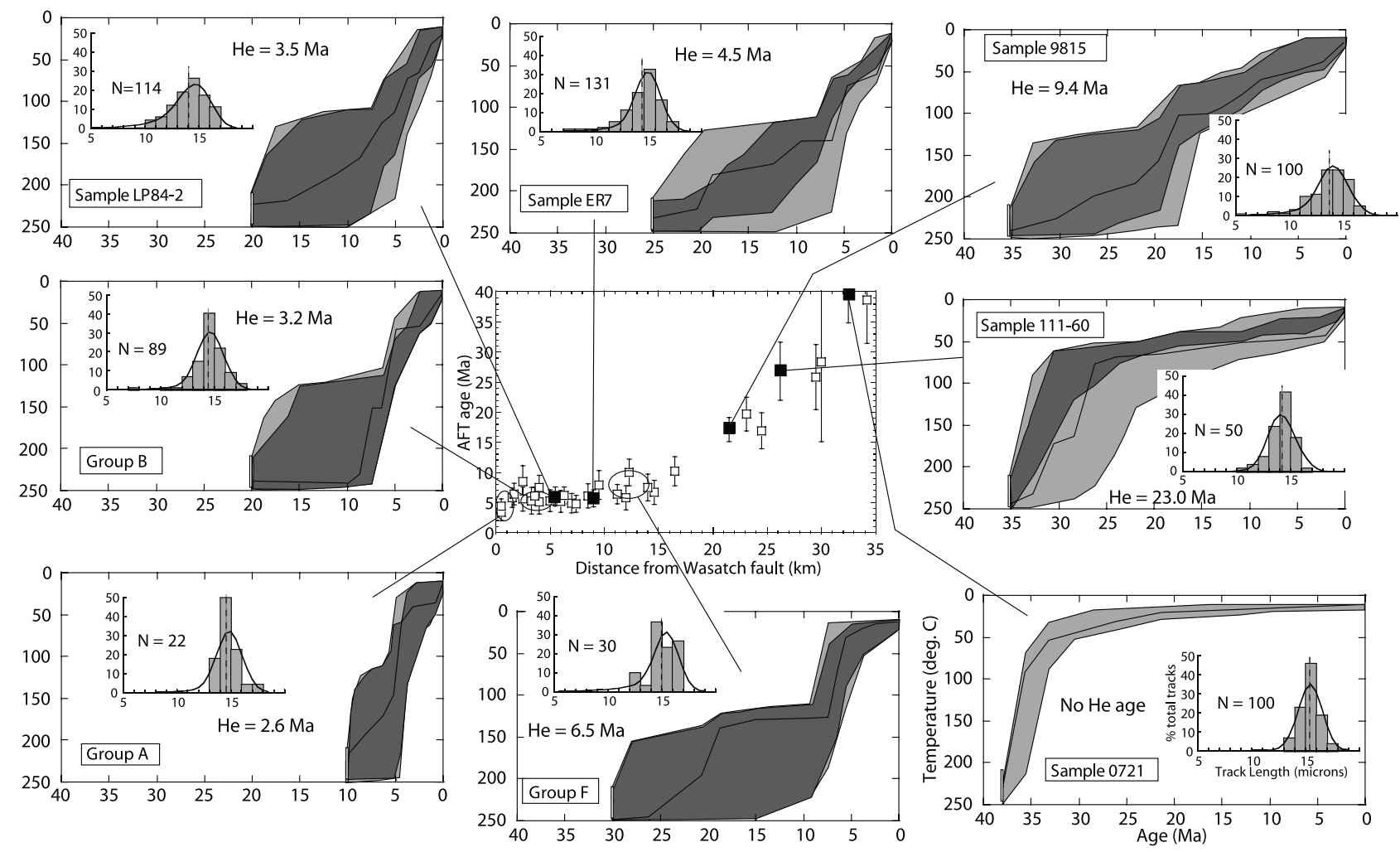

Figure 6. Modeled temperature history plots and track length distributions for selected samples and sample group data sets. See Table 3 for model parameters and text for discussion. Statistically "acceptable" temperature history results, with merit function values $>0.05$ [see Ketcham et al., 2000], are shown by the light shaded regions. Darker shaded regions represent the range of acceptable AFT temperature histories that also produce model (U-Th)/He ages that agree with measured ages (within $2 \sigma$ ). The middle curve in each temperature history is the AFT-derived best fit temperature history curve for each group or sample. The measured (U-Th)/He age is shown by "He =". Inset histograms show the measured (binned) and best fit model (solid curve) track length distributions and mean track length (dashed vertical line) for the sample or group. Axis labels for all temperature-time plots are the same as in lower right plot.

paleodepth. This age was not replicated and may have unrecognized high-uranium inclusions that lead to an anomalously old age for this sample. The average (U-Th)/He age of the nearby samples is $4.5 \pm 0.5 \mathrm{Ma}$, which represents a better age for rocks from this area. The dark gray envelope of acceptable temperature histories for sample ER7 in Figure 6 reflects this average (U-Th)/He age. The higher temperature portions of the models are poorly constrained because the apatite fission track annealing and helium diffusion models are insensitive to temperatures above about 130 and $100^{\circ} \mathrm{C}$, respectively. However, assuming a minimum zircon annealing temperature of $210-250^{\circ} \mathrm{C}$, samples adjacent to the Wasatch fault underwent rapid cooling from greater than $200^{\circ} \mathrm{C}$ to less than $50^{\circ} \mathrm{C}$ in the last $10 \mathrm{Myr}$. This rapid cooling event is common to all the sample simulations from the western $17 \mathrm{~km}$ of the range.

Table 3. Fission Track Modeling Parameters

\begin{tabular}{|c|c|c|c|c|c|c|}
\hline $\begin{array}{l}\text { Sample } \\
\text { or Group }\end{array}$ & $\begin{array}{c}\text { Number of } \\
\text { Samples }\end{array}$ & $\begin{array}{c}\text { Mean Age, } \\
\text { Ma }\end{array}$ & $\begin{array}{c}\text { Mean Length, } \\
\mu \mathrm{m}\end{array}$ & $\begin{array}{l}\text { Number of } \\
\text { Lengths }\end{array}$ & $\begin{array}{c}\mathrm{ZFT}^{\mathrm{b}} \\
\mathrm{Ma}\end{array}$ & $\begin{array}{c}(\mathrm{U}-\mathrm{Th}) / \mathrm{He}^{\mathrm{c}}{ }^{\mathrm{c}} \\
\mathrm{Ma}\end{array}$ \\
\hline A & 3 & 4.6 & 14.7 & 22 & 10 & $2.6(1.4)$ \\
\hline $\mathrm{B}$ & 5 & 5.6 & 14.4 & 89 & 20 & $3.2(0.6)$ \\
\hline LP84-2 & 1 & 5.2 & 14.0 & 114 & 20 & $3.5(0.5)$ \\
\hline ER7 & 1 & 5.7 & 13.7 & 131 & 25 & $4.5(0.5)^{\mathrm{d}}$ \\
\hline $\mathrm{F}$ & 3 & 8.0 & 15.0 & 30 & 30 & $6.5(1.3)$ \\
\hline 9815 & 1 & 17.1 & 13.7 & 100 & 35 & $9.4(0.5)$ \\
\hline $111-60$ & 1 & 26.8 & 14.1 & 50 & 35 & $23(2.1)$ \\
\hline 0721 & 1 & 39.6 & 15.4 & 100 & 38 & - \\
\hline
\end{tabular}

${ }^{a}$ Mean age of single grain ages for samples in group.

${ }^{\mathrm{b}} \mathrm{ZFT}$ is zircon fission track age.

${ }^{c}(\mathrm{U}-\mathrm{Th}) / \mathrm{He}$ age is average of ages in a group. Number in parentheses is sample or group uncertainty. Group uncertainties are at $1 \sigma$.

${ }^{\mathrm{d}}$ Sample ER7 (U-Th)/He age is average of nearby samples (see text). 


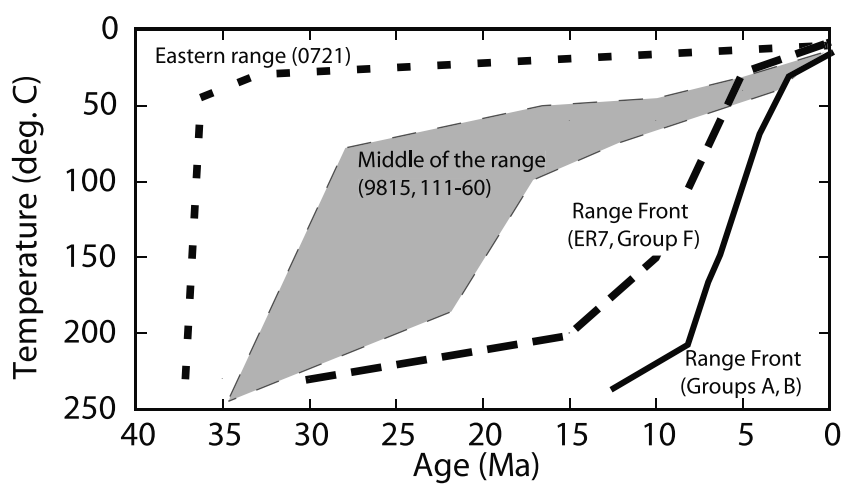

Figure 7. Representative temperature history plots for four regions across the Wasatch Range. Representative sample and group numbers (Figure 6) are shown in parentheses.

\subsection{Middle of the Range: 22 to $26 \mathrm{~km}$}

[31] AFT data from two samples at $22 \mathrm{~km}$ (sample 9815) and $26 \mathrm{~km}$ (sample 111-60) were modeled for the middle part of the range. Both have well-determined AFT ages and duplicated (U-Th)/He ages (Tables 1 and 2). Mean track lengths are 13.7 to $14.1 \mu \mathrm{m}$ and indicate relatively rapid cooling through the apatite PAZ. However, track length distributions are negatively skewed with some tracks as short as $10-11 \mu \mathrm{m}$ implying that the samples may have spent significant time at temperatures within the apatite PAZ. A significant difference in these two samples is a doubling of (U-Th)/He age over a distance of $5 \mathrm{~km}$.

[32] Modeling of these samples indicates that they cooled earlier than those at the range front (Figures 6 and 7). The $22 \mathrm{~km}$ sample shows a best fit temperature history with cooling from about $150^{\circ} \mathrm{C}$ to $<100^{\circ} \mathrm{C}$ between 25 and 15 $\mathrm{Ma}$, followed by slower cooling in the last $10 \mathrm{Myr}$. Forward modeling results for (U-Th)/He ages are consistent with the lower temperature portion of the "acceptable" temperature history envelope. Modeling results indicate that this sample was at a temperature of less than about $75^{\circ} \mathrm{C}$ at $10 \mathrm{Ma}$ when the westernmost range front samples were $>150^{\circ} \mathrm{C}$.

[33] The best fit models for the $26 \mathrm{~km}$ sample show rapid cooling from greater than $150^{\circ} \mathrm{C}$ to $50-60^{\circ} \mathrm{C}$ between 30 and $25 \mathrm{Ma}$ followed by slow cooling (Figure 6). Modeled (U-Th)/He ages are consistent with the lower temperature "acceptable" AFT-derived history curves (Figure 6).

[34] Both samples from this region indicate cooling prior to the cooling/unroofing event in the last $10 \mathrm{Myr}$ for the range front samples (Figure 7). These middle of the range samples show relatively rapid cooling between 30 and 20 $\mathrm{Ma}$ and relatively slow cooling from temperatures of about $50-75^{\circ} \mathrm{C}$ in the last $10 \mathrm{Myr}$. The early, more rapid phase of cooling occurred earlier in time for the eastern sample (11160) than for the western sample (9815). This relationship may be related to sample 111-60 being exhumed earlier and/ or intruded at a shallower depth.

\subsection{Eastern Part of the Range: 30 to $35 \mathrm{~km}$}

[35] Acceptable temperature histories for the easternmost samples indicate very rapid cooling between 40 and $30 \mathrm{Ma}$, followed by near isothermal conditions at $<60^{\circ} \mathrm{C}$ to the present (Figures 6 and 7). The samples east of $30 \mathrm{~km}$ from the Wasatch fault record rapid cooling that is consistent with intrusion emplacement at very shallow depths $(\sim 1 \mathrm{~km})$.

\section{Sample Paleodepth}

[36] Several lines of evidence outlined earlier lead to the interpretation that the Wasatch Mountains have tilted eastward so that the westernmost part of the Cottonwood Intrusive Belt was initially at a paleodepth of $11 \mathrm{~km}$ or more [i.e., Parry and Bruhn, 1987; John, 1989]. However, it is unclear whether or not one simple continuous tilt event was responsible for the unroofing, or if more than one event with changes in the locus of unroofing through time was responsible. The simplest scenario is to assume one tilt event about a hinge located in the Keetley Volcanics about $35-40 \mathrm{~km}$ east of the Wasatch fault. Computed paleodepths for all samples assuming one tilt event and $11 \mathrm{~km}$ paleodepth for the westernmost samples are shown in Figure 8a, and the method for computing paleodepth is shown in Figure 9.

[37] With the single tilt model, both AFT and (U-Th)/He ages increase slightly with decreasing paleodepth until about $3 \mathrm{~km}$ paleodepth where both AFT and (U-Th)/He ages increase abruptly. A single tilt scenario would place the Alta and Clayton Peak stock samples (Table 1) about $3 \mathrm{~km}$ deep prior to being exhumed. An interpretation of the increasing ages above about $3 \mathrm{~km}$ paleodepth (Figure 8a) is that these middle part of range Alta and Clayton Peak stock samples are from within and define the PAZ $\left(60-110^{\circ} \mathrm{C}\right)$ and helium PRZ $\left(40-80^{\circ} \mathrm{C}\right)$ for apatite. Studies of other areas have shown similar paleodepth definition of the PAZ and PRZ for single tilt events [e.g., Stockli et al., 2000]. Applying the temperature ranges for the apatite PAZ and PRZ implies a paleogeothermal gradient of $20-25^{\circ} \mathrm{C} \mathrm{km}^{-1}$ in the upper few kilometers of the crust for this single tilt event.

[38] There are several problems with the single tilt scenario. First, fluid inclusion and metamorphic mineral assemblage studies show that samples from Alta stock were intruded at depths that range from $3.7 \mathrm{~km}$ for eastern parts of the intrusion to $6.3 \mathrm{~km}$ for the western parts [Cook, 1982; John, 1989, 1991]. Two of the three Alta Stock samples are from the western half of the intrusion and were intruded at depths that are about two times greater than predicted by the single tilt scenario. Second, single tilt paleodepths lead to temperatures of $70-80^{\circ} \mathrm{C}$ (within the apatite PAZ; Figure 8a) for the time period between intrusion and exhumation. The long track lengths (mean lengths of 13.7-15.4 $\mu \mathrm{m}$ ) indicate that most of the samples were not intruded into the apatite PAZ. Third, extensive fluid inclusion analysis of fault rocks [Parry and Bruhn, 1986, 1987] indicates that the westernmost part of the Little Cottonwood stock was at minimum temperature of $285^{\circ} \mathrm{C}\left( \pm 29^{\circ} \mathrm{C}\right.$ at $\left.1 \sigma\right)$ prior to exhumation. Nonlinear extrapolation of the paleogeothermal gradient of $20-25^{\circ} \mathrm{C} \mathrm{km}{ }^{-1}$ predicted by single tilt scenario apatite PAZ and PRZ depths, which accounts for heat production in the upper crust [e.g., Chapman, 1986], places the deepest samples at depths corresponding to 200$240^{\circ} \mathrm{C}$ prior to tilt.

[39] One could invoke geothermal gradients greater than $20-25^{\circ} \mathrm{C} \mathrm{km}^{-1}$ to raise the temperatures of the deepest samples and the high and low temperature limits of the apatite PAZ and PRZ. Note that the geothermal gradient 

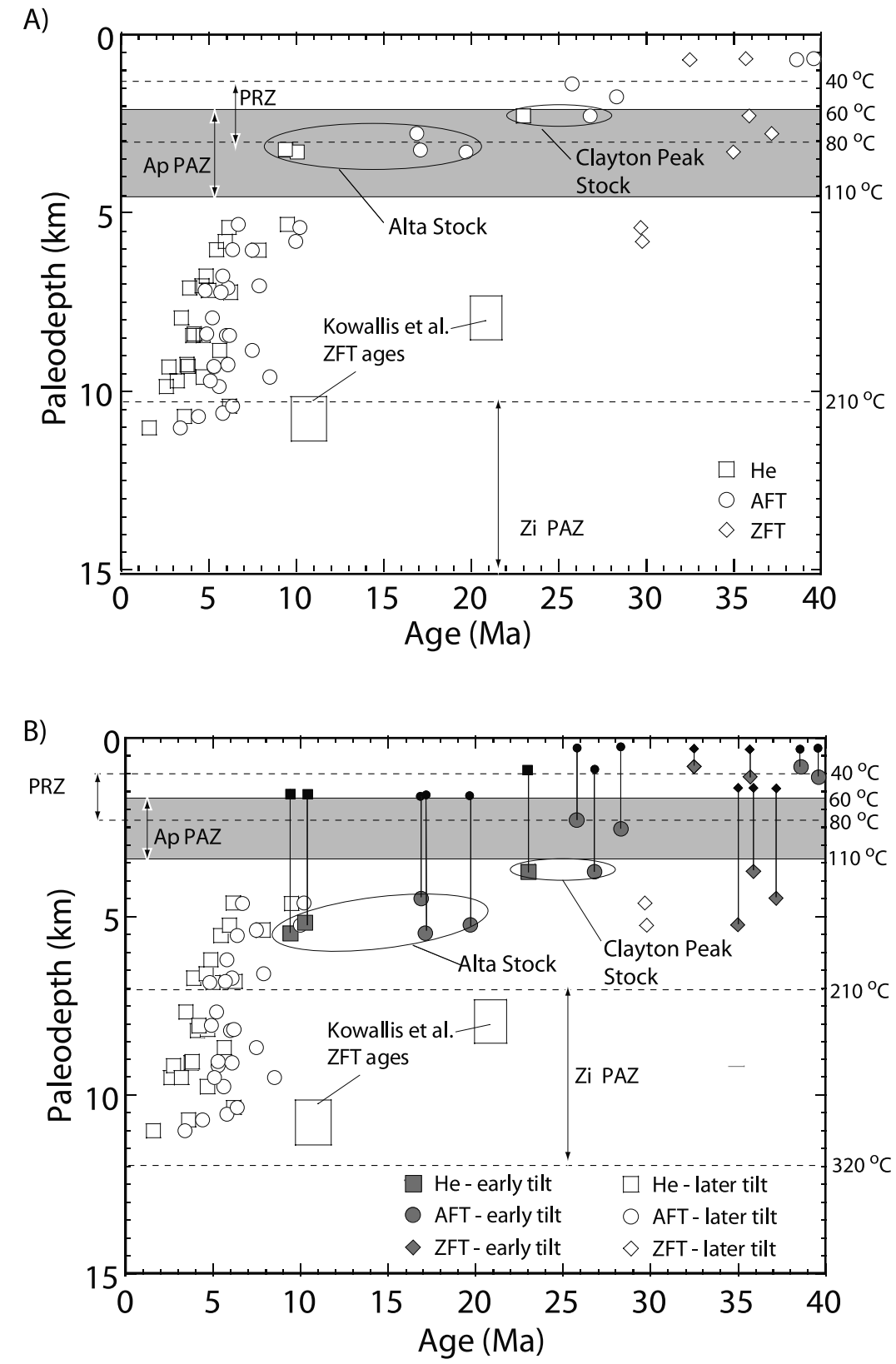

Figure 8. Sample paleodepth versus thermochronometer age plots (a) for a single tilt event and (b) for two tilt events. In the single tilt scenario, samples are projected below a tilted paleohorizontal surface with hinge located $38 \mathrm{~km}$ east of the Wasatch fault (see Figure 9). In the two tilt scenario, the early and later tilt events have hinges located 38 and $25 \mathrm{~km}$ east of the Wasatch fault, respectively. Vertical tie lines for early tilt samples in Figure 8b reflect the amount that these samples are moved toward the surface in the early tilt event. The solid symbol at the upper end of tie line is the depth of sample prior to a later tilt. Numbers on sides are temperatures corresponding to the tops and bottoms of the partial annealing and partial retention zones. In Figure $8 \mathrm{a}$ the bottom of the zircon PAZ $\left(a t 320^{\circ} \mathrm{C}\right.$ ) is off the depth range of plot. Temperatures at indicated paleodepths were computed by accounting for crustal heat production [Chapman, 1986] and using the thermophysical properties given by Ehlers et al. [2003]. PRZ, partial retention zone; Ap PAZ, apatite partial annealing zone; Zi PAZ, zircon partial annealing zone. See text for discussion.

probably was higher at times during the Oligocene due to volcanism as indicated by low zircon $P\left(\chi^{2}\right)$ values. However, unless the geothermal gradient was greater than about $50^{\circ} \mathrm{C} \mathrm{km}^{-1}$, the Alta and Clayton Peak samples would have resided in the apatite PAZ until they began to cool during exhumation in the last 10 Myr. If the intrusion depths deduced from fluid inclusions and metamorphic mineral assemblages are accepted, then these high geothermal gradients at the start of exhumation can be ruled out because acceptable thermal histories show that these samples (11160 and 9815) had largely passed through the apatite PAZ by $10 \mathrm{Ma}$ (Figures 6 and 7).

[40] Problems with the single tilt scenario lead to a preferred, but slightly more complex, scenario that includes 


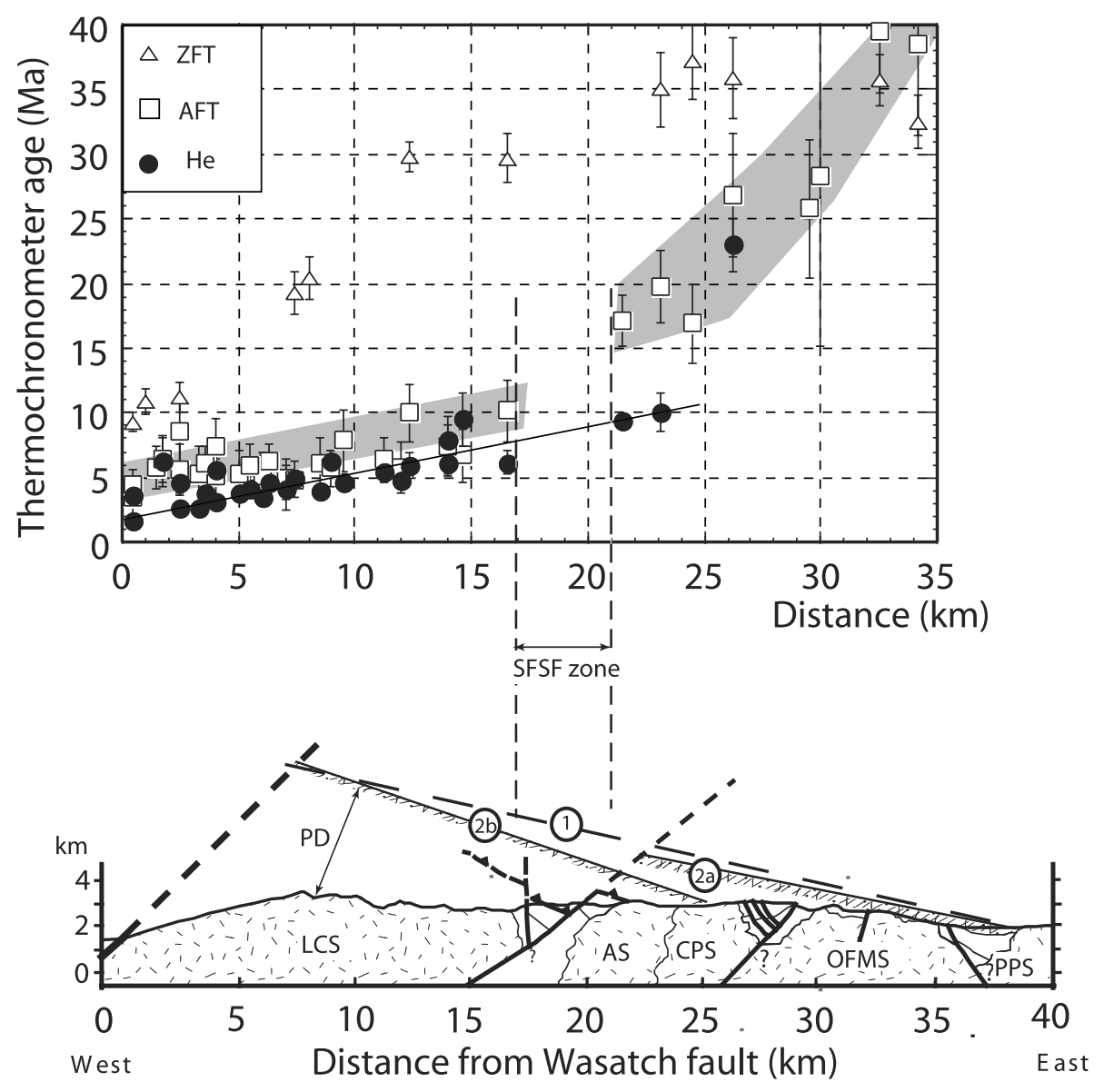

Figure 9. Combined apatite fission track, zircon fission track, and (U-Th)/He data sets versus distance from the Wasatch fault. Distance axis is same as in Figure 3. Solid line on plot is the best linear fit to the (U-Th)/He data. Plot does not include the apatite fission track data for samples 9817 and 9818, which are well north of the main sample transect. Shaded region represents the age trend for the apatite fission track data. Cross section below age plot shows positions of thermochronologic data relative to geologic features. Numbered lines above the cross section represent stylized locations of paleohorizontal surfaces for one tilt (dashed; labeled as 1) and two tilts (solid hatchured; labeled as 2). Tilt 2a and $2 \mathrm{~b}$ are the earlier and later tilt events, respectively. Paleodepths (PD) of samples measured relative to the tilted surfaces. SFSF, Silver Fork-Superior Fault. Other abbreviations are as in Figure 2.

two tilt events. We consider a two-stage history such that the eastern and middle of the range samples were tilted by an early tilt event and the western samples (within $17 \mathrm{~km}$ of the Wasatch fault) were tilted later. Middle and eastern range sample paleodepths were computed by projecting them below a $15^{\circ}$ dipping surface with hinge located $38 \mathrm{~km}$ east of the Wasatch fault and the western samples were projected below a $20^{\circ}$ surface with hinge at $25 \mathrm{~km}$ from the Wasatch fault (Figure 9). The $25 \mathrm{~km}$ hinge location for the later tilt event was chosen for the following reasons. First, (U-Th)/ He ages continue a linear trend across the Silver Fork Superior faults to about $22 \mathrm{~km}$ where the ages increase twofold to $23 \mathrm{Ma}$ and are concordant with AFT ages. Thus the hinge must be near the location of the $23 \mathrm{Ma}(\mathrm{U}-\mathrm{Th}) / \mathrm{He}$ age location at $27 \mathrm{~km}$ to minimize later exhumation at this location. Second, thermokinematic models of samples from the western part of the range that minimize differences between measured and modeled (U-Th)/He ages with two free parameters, hinge distance and exhumation rate adja- cent to the fault [Ehlers et al., 2003], are best fit by a 20-25 $\mathrm{km}$ hinge distance. The middle of the range and eastern samples then were initially at paleodepths as great as $5.5 \mathrm{~km}$ and samples from farther west were at depths of 5 to $11 \mathrm{~km}$ (Figure 8b). This scenario puts the eastern Little Cottonwood Stock and Alta Stock samples at about the same depth and at temperatures greater than the apatite PAZ (Figure 8b) prior to any tilt or exhumation. Assuming the 10 to $30 \mathrm{Ma}$ ZFT ages reflect the zircon PAZ, a paleogeothermal gradient of $35 \pm 5^{\circ} \mathrm{C} \mathrm{km}^{-1}$ is implied for the upper few kilometers of the crust. Note that computed depths to the tops and bottoms of the PAZ and PRZ account for crustal heat production using the data of Ehlers et al. [2003] and therefore the temperature gradients decrease with increasing depth (Figure 8).

[41] In the early tilt event, the middle and eastern samples are moved upward to depths of $\sim 1.5 \mathrm{~km}$ or less. These samples are fully exhumed in the last 10-12 Myr during the tilt event that unroofs the western samples. An important 
implication of this two-stage scenario is that the hinge of rotation effectively moves west prior to the later tilt because the middle and eastern samples were at shallow depths and at temperatures less than those of the apatite PAZ prior to the final unroofing. Thus a simple two-stage tilt scenario fits all of the paleodepth considerations better than a single tilt scenario.

\section{Interpretations of the Cooling Patterns and Tilt of the Central Wasatch}

[42] Concordance of AFT and ZFTages (Figure 9) and U/Pb crystallization ages for the easternmost $(33-38 \mathrm{~km}$ from the fault) porphyry stocks strongly suggest that they all record the age of emplacement. Age concordance, the fine-grained groundmass of these intrusions, and AFT modeling all indicate rapid cooling from emplacement temperatures. For a geothermal gradient of $35^{\circ} \mathrm{C} \mathrm{km}^{-1}$ and assuming postintrusion age temperatures of less than about $60^{\circ} \mathrm{C}$ as indicated by fission track modeling, the intrusion depth would have been $1.0-1.5 \mathrm{~km}$. For higher initial (Oligocene) geothermal gradients that may have caused resetting of some zircon fission track ages and thus the observed large age dispersion, the depth estimates would be even lower. These depth estimates are consistent with a depth estimate of $<1.3 \mathrm{~km}$ for these porphyry intrusions based on fluid inclusion data [John, 1989].

[43] In the middle of the range $(22-27 \mathrm{~km}$ from the fault), samples cooled about $100^{\circ} \mathrm{C}$ between 30 and $15 \mathrm{Ma}$ depending on distance east. This cooling may be related to an initial unroofing event (Figure 10) that is coincident with early-middle Miocene rapid cooling/unroofing elsewhere in the Great Basin [e.g., Fitzgerald et al., 1991; Stocki and Linn, 1996; Dumitru et al., 1997; Miller et al., 1999]. Constenius [1996, 1998] proposed that this part of the Wasatch was unroofed in late Eocene to middle Miocene time due to extensional collapse and metamorphic core complex formation bound to the south by the Deer Creek Fault system. Evidence for this extensional unroofing event includes extensional growth strata of the late Eocene to Oligocene Tibble Formation in the hanging wall of the Deer Creek Fault, Oligocene dikes cut by detachment faults, and rapid cooling of the Alta stock in the footwall of the Deer Creek Fault [Constenius, 1998].

[44] The decrease in AFT ages toward the range front between 22 and $17 \mathrm{~km}$ from the Wasatch Fault is coincident with the location of the Silver Fork-Superior fault system (Figure 9). This coincidence implies that the Silver ForkSuperior fault system was active during the late Oligocene early Miocene cooling/unroofing event. The fault system would have acted to partition unroofing such that to the east the samples at $22-27 \mathrm{~km}$ from the fault cooled as discussed above, but west of the faults the samples would have resided at temperatures greater than $120^{\circ} \mathrm{C}$ until $10-12 \mathrm{Ma}$ or later. On the basis of cooling patterns and paleodepth analysis, we interpret $\sim 15^{\circ}$ of eastward tilt of the Wasatch in the late Oligocene-middle Miocene. This tilting corresponds to $\sim 3.5 \mathrm{~km}$ of differential erosion on either side of the Silver Fork fault system. However, subsurface and aerial projection of contacts in geologic cross sections suggests that the faults only have about $1.5 \mathrm{~km}$ of offset [Crittenden, 1965]. Even though this major fault zone appears to divide the range into two tilt regions, the precise reason for the differential exhumation not accounted for by faulting is unknown at this time. We offer two potential mechanisms to account for this discrepancy. First, some of the fault offset deficit may have been accommodated by intense folding partially preserved in the metasedimentary rocks between the Silver Fork fault and the Little Cottonwood Stock to the west; much of the potential folding may have been removed by erosion above the intrusions. Second, an additional $1-1.5 \mathrm{~km}$ of relief on the east side of the Silver Fork fault system relative to the west side prior to the early tilt could account for much of the difference between fault offset and exhumation. Indeed, the Silver Fork fault footwall region was the locus of most of the earlier thrust faulting in the area and probably was elevated relative to the areas to the west.

[45] The continuation of the (U-Th)/He age trend across the Silver Fork-Superior fault zone (Figure 9) indicates that the fault system became relatively inactive by about $10 \mathrm{Ma}$. Strain concentration may have shifted at this time from the Silver Fork-Superior fault zone westward to the present Wasatch Fault (Figure 10). The decreasing AFT and (U-Th)/He ages toward the mountain front are the result of continued eastward tilt after the Silver Fork-Superior fault system became inactive and displacement shifted to the Wasatch fault. The initiation of this phase of cooling and unroofing began 10-12 Ma, as shown by the best fit temperature history models for the sample group F located just west of the Silver Fork-Superior fault zone (Figures 6 and 7). This timing is consistent with the cooling duration modeling of Ehlers et al. [2003].

[46] In addition to an overall westward stepping of faulting in the central Wasatch, our data and modeling lead to the interpretation that the effective hinge location of eastward tilt also migrated westward. During the early stage of exhumation and tilt, the hinge position was located more than $30 \mathrm{~km}$ east of the Wasatch fault to allow the progressive exhumation of samples between 33 and $22 \mathrm{~km}$. The later stage of tilting occurred about a hinge that was located farther west at about $25 \mathrm{~km}$ from the Wasatch fault as described in the Sample Paleodepth section earlier.

\section{Discussion}

[47] The data and analysis presented in this study are consistent with a two-stage model of unroofing in which the locus of exhumation and effective hinge position migrated westward in the Cottonwood Intrusive Belt area (Figure 10). The Oligocene to middle Miocene stage may have been associated with initial metamorphic core complex formation that was partitioned to the west by the Silver Fork-Superior fault system and to the south by the Deer Creek fault [Constenius, 1998]. The late Miocene to recent phase is interpreted as a continuation of the earlier deep-level unroofing and eastward tilting. Positions of the hinge locations at about 35 and $25 \mathrm{~km}$ for the early and late tilt phases correspond spatially with the locations of multiple intrusion intersections and fault systems (Figure 9). The faulted regions between the intrusions may have been local areas of weakness that acted as hinges to flexural-isostatic uplift caused by continued unloading of the hanging wall and compensation of the previously overthickened crustal welt as proposed by Constenius [1998]. The overall west- 

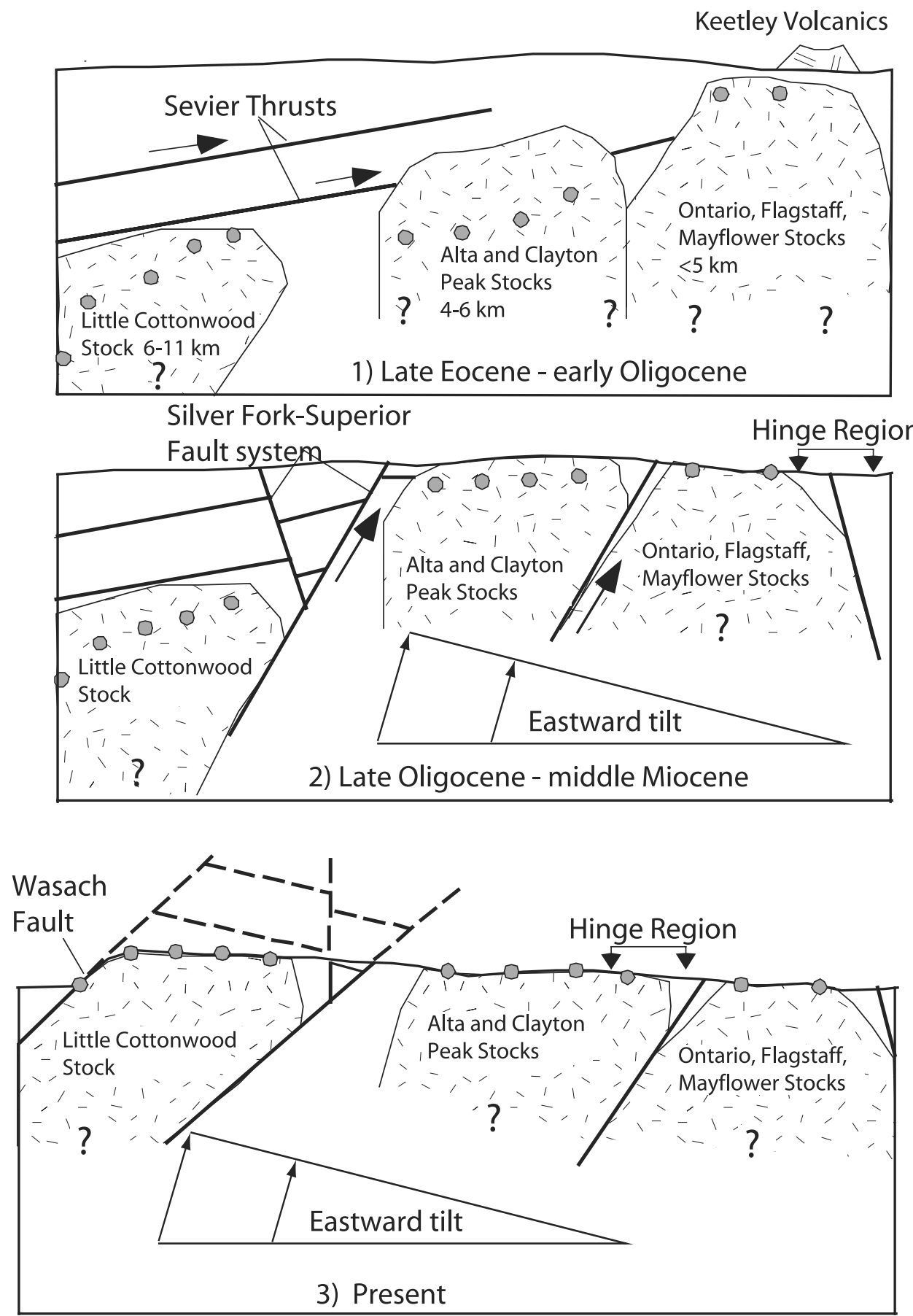

Figure 10. Schematic diagram showing a three-stage interpretation of the spatial and temporal variation in exhumation across the central Wasatch that is consistent with the thermochronologic data. Gray dots represent relative locations of exhumed sample locations through the three time stages.

ward migration of both exhumation and hinge position occurred in time and space similar to that predicted by a "rolling-hinge" model [e.g., Spencer, 1984; Buck, 1988; Hamilton, 1988; Wernicke and Axen, 1988]. This interpretation is largely consistent with the Oligocene to Miocene extensional collapse unroofing event of Constenius [1998], but proposes that the localized core complex development has continued during the last $10 \mathrm{Myr}$ when most of the exhumation occurred along the western range front in the Cottonwood Intrusive Belt area. Later exhumation was enhanced by more typical Basin and Range-type faulting that has affected most of the rest of the Wasatch front at lower exhumation magnitudes and rates. These lower rates are interpreted from (U-Th)/He ages for the northern Salt Lake segment and other segments of the Wasatch fault footwall that are 2-3 times the ages of the youngest samples at the same elevation just south of Little Cottonwood Canyon [Taylor et al., 2001]. The (U-Th)/He ages at the range front for the other segments, and the exhumation rates that they represent, may be more typical of the 
Miocene to recent Basin and Range faulting along the Wasatch fault.

[48] Fission track modeling and paleodepth analysis imply that more than $5 \mathrm{~km}$ of differential exhumation occurred across the western $20 \mathrm{~km}$ of the central Wasatch Mountains in the Little Cottonwood Canyon area since 10$12 \mathrm{Ma}$; during this time, less than $2 \mathrm{~km}$ was eroded from the Alta-Clayton Peak stocks and other areas east of the Silver Fork-Superior fault system (Figure 10). In our exhumation analysis, we do not differentiate between cooling due to tectonic unroofing and surface erosion. Clearly, Figure 9 shows that the process of tectonic unroofing dominates in the western $8 \mathrm{~km}$ and surface erosion dominates between about 8 and $20 \mathrm{~km}$ from the Wasatch fault. The convex outward nature of the western $8 \mathrm{~km}$ of the range front and the consistency of the ridge top elevations farther east (Figure 9) probably reflect the contributions of tectonic unroofing and surface erosion. However, the consistent increase in thermochronometer age with distance from the Wasatch fault, especially the (U-Th)/He ages, imply that the cooling was largely a continuous process, whether by tectonic unroofing or erosion. If significant cooling by erosion had been occurring between 8 and $20 \mathrm{~km}$ from the fault prior to tilt in the last $10-12 \mathrm{Myr}$, then an abrupt increase in ages would be expected east of $\sim 8 \mathrm{~km}$ from the fault. In the thermokinematic models of Ehlers et al. [2003], the age-distance trends are reproduced assuming simple tilt scenarios that account for vertical and horizontal motion of rock volumes toward a steady state topographic surface both adjacent to the fault and at all distances from the fault. Thus the age patterns are consistent with time-continuous erosion and tectonic unroofing that has maintained a dynamic steady state topographic profile for the last 10-12 Myr.

\section{Conclusions}

[49] In this study, we used a dense sample array of apatite (U-Th)/He, apatite fission track, and zircon fission track data to constrain the timing, rate, and style of late Tertiary exhumation of the Cottonwood Intrusive Belt (CIB) in the central Wasatch Mountains, which are often cited as an example of intracontinental rift flank uplift and exhumation. The combined use of these thermochronometers, evaluated both spatially and as a function of elevation, indicates a two-stage exhumation history in which the locus of tilting and exhumation migrated westward. This range front directed migration is similar to that predicted by a rolling-hinge model of extensional tectonic development. The first stage includes a post-pluton-emplacement exhumation period in the Oligocene - middle Miocene, with much of the faulting associated with the exhumation concentrated east of the Silver Fork-Superior fault system and north of the Deer Creek fault. This interpretation is consistent with late Eocene to middle Miocene rapid tilting and exhumation associated with metamorphic core complex formation in the CIB area. The western part of the CIB area later tilted eastward about a hinge located $\sim 25 \mathrm{~km}$ east of the Wasatch fault during a second stage of tilting and rapid exhumation in the last $10-12$ Myr. The relatively high late Miocene to recent exhumation rate and magnitude in the western CIB is anomalous relative to the rest of the Wasatch footwall segments and may represent a continuation of the earlier exhumation event superimposed on later Basin and Range fault-related uplift and exhumation along the eastern rift flank of the Basin and Range province.

[50] Acknowledgments. We thank W. Parry, R. Bruhn, B. Kowallis, and $\mathrm{K}$. Constenius for supplying sample splits for this study and E. Reinert, L. Cannon, M. Perkins, and L. Hedges for help with sample collection and preparation. Discussions of Wasatch geology with J. Bartley, R. Bruhn, B. Kowallis, and K. Constenius are greatly appreciated. R. Donelick supplied the Cf-252 irradiations. This paper greatly benefited from reviews by R. Ketcham, S. Thompson, and Associate Editor J. Braun. Research was funded by NSF grant EAR-9805073 to Armstrong and Chapman.

\section{References}

Armstrong, P. A., T. A. Ehlers, P. J. J. Kamp, K. A. Farley, and D. S. Chapman, Tracking changes in exhumation rates using low-temperature thermochronometry: An example from the Wasatch Mountains, Utah (USA), in 9th International Conference on Fission Track Dating and Thermochronology, Abstr. Ser., vol. 58, edited by W. P. Noble, P. B. O’Sullivan, and R. W. Brown, pp. 5-7, Geol. Soc. of Aust., Lorne, 2000 .

Axen, G. J., M. Grove, D. Stockli, O. M. Lovera, D. A. Rothstein, J. M. Fletcher, K. A. Farley, and P. L. Abbott, Thermal evolution of Monte Blanco dome: Low-angle normal faulting during Gulf of California rifting and late Eocene denudation of the eastern Peninsular Ranges, Tectonics, 19, 197-212, 2000.

Baker, A. A., F. C. Calkins, M. D. J. Crittenden, C. S. Bromfield, Geologic map of the Brighton quadrangle, Utah, U. S. Geol. Surv. Geol. Quad. Map, GQ-534, 1966.

Blythe, A. E., D. W. Burbank, K. A. Farley, and E. J. Fielding, Structural and topographic evolution of the central Transverse Ranges, California, from apatite fission-track, (U-Th)/He and digital elevation model analyses, Basin Res., 12, 97-114, 2000.

Brandon, M. T., M. K. Roden-Tice, and J. I. Garver, Late Cenozoic exhumation of the Cascadia accretionary wedge in the Olympic Mountains, northwest Washington State, Geol. Soc. Am. Bull., 110, 985-1009, 1998.

Braun, J., Quantifying the effect of recent relief changes on age-elevation relations, Earth Planet. Sci. Lett., 200, 331-343, 2002.

Bromfield, C. S., S. J. Erickson Jr., M. A. Haddadin, and H. J. Menhert, Potassium-argon ages of intrusion, extrusion, and associated ore deposits, Park City mining district, Utah, Econ. Geol., 72, 837-848, 1977.

Bryant, B., Geologic map of the Salt Lake City $30^{\prime} \times 60^{\prime}$ Quadrangle, north-central Utah, and Uinta County, Wyoming, U. S. Geol. Surv. Misc. Invest. Ser. Map, I-1944, 1990.

Bryant, B., Geologic and structure maps of the Salt Lake City $1^{\circ} \times 2^{\circ}$ Quadrangle, Utah and Wyoming, U. S. Geol. Surv. Misc. Invest. Ser. Map, I-1997, 1992.

Buck, W. R., Flexural rotation of normal faults, Tectonics, 7, 959-973, 1988.

Carlson, W. D., R. A. Donelick, and R. A. Ketcham, Variability of apatite fission-track annealing kinetics, I, Experimental results, Am. Mineral., 84, $1213-1223,1999$.

Chapman, D. S., Thermal gradients in the continental crust, in The Nature of the Lower Ccontinental Crust, edited by J. B. Dawson, J. Hall, and K. H. Wedepohl, Geol. Soc. Spec. Publ., 24, 63-70, 1986.

Constenius, K. N., Late Paleogene extensional collapse of the Cordilleran foreland fold and thrust belt, Geol. Soc. Am. Bull., 108, 20-39, 1996.

Constenius, K. N., Extensional tectonics of the Cordilleran foreland fold and thrust belt and the Jurassic-Cretaceous Great Valley forearc basin, Ph.D. thesis, Univ. of Ariz., Tuscon, 1998.

Cook, S. J., The physical-chemical conditions of contact skarn formation at Alta, Utah, M.Sc. thesis, Univ. of Utah, Salt Lake City, 1982.

Cowie, P. A., and C. H. Scholz, Growth of faults by accumulation of seismic slip, J. Geophys. Res., 97, 11,085-11,095, 1992.

Crittenden, M. D., Jr., Geology of the Dromedary Peak Quadrangle, Utah, U. S. Geol. Surv. Geol. Quad. Ma, GQ-378, 1965.

Donelick, R. A., and D. S. Miller, Enhanced TINT fission track densities in low spontaneous track density apatites using 252CF-derived fission fragment tracks: A model and experimental observations, Nucl. Tracks Radiat. Meas., 18, 301-307, 1991.

Dumitru, T. A., Fission-track geochronology in Quaternary geology, in Quaternary Geochronology: Methods and Applications, AGU Ref. Shelf, vol. 4, edited by J. S. Noller, J. M. Sowers, and W. R. Lettis, pp. 131 156, AGU, Washington, D. C., 2000.

Dumitru, T. A., E. L. Miller, D. F. Stockli, and B. E. Surpless, Fission track constraints on time-space patterns of Miocene extension in the northern Basin and Range province, Geol. Soc. Am. Abstr. Programs, 29, A-232, 1997. 
Ehlers, T. A., P. A. Armstrong, and D. S. Chapman, Normal fault thermal regimes and the interpretation of low-temperature thermochronometers, Phys. Earth Planet. Inter., 126, 179-194, 2001.

Ehlers, T. A., S. D. Willett, P. A. Armstrong, and D. S. Chapman, Exhumation of the central Wasatch Mountains, Utah: 2. Thermokinematic model of exhumation, erosion, and thermochronometer interpretation, J. Geophys. Res., 108, doi:10.1029/2001JB001723, in press, 2003.

Evans, S. H., W. T. Parry, and R. L. Bruhn, Thermal, mechanical, and chemical history of Wasatch fault cataclasite and phyllonite, Traverse Mountains area, Salt Lake City, Utah: Age and uplift rates from $\mathrm{K} / \mathrm{Ar}$ and fission track measurements, U.S. Geol. Surv. Open File Rep., 86-31, 410-415, 1985

Farley, K. A., Helium diffusion from apatite: General behavior as illustrated by Durango fluorapatite, J. Geophys. Res., 105, 2909-2914, 2000.

Farley, K. A., R. A. Wolf, and L. T. Silver, The effects of long alphastopping distances on (U-Th)/He ages, Geochim. Cosmochim. Acta, 60, 4223-4229, 1996

Feher, L., T. A. Vogel, and K. N. Constenius, Relationships between the Wasatch intrusive belt and the Keetley volcanics, north central Utah, Geol. Soc. Am. Abstr. Programs, 28, A-483, 1996.

Fitzgerald, P. G., J. E. Fryxell, and B. P. Wernicke, Miocene crustal extension and uplift in southeastern Nevada: Constraints from fission track analysis, Geology, 19, 1013-1016, 1991

Galbraith, R. F., On statistical methods of fission track counts, Math. Geol., $13,471-478,1981$

Galbraith, R. F., and G. M. Laslett, Statistical models for mixed fission track ages, Nucl. Tracks Radiat. Meas., 21, 459-470, 1993.

Green, P. F., I. R. Duddy, G. M. Laslett, K. A. Hegarty, A. J. W. Gleadow, and J. F. Lovering, Thermal annealing of fission tracks in apatite, 4, Quantitative modelling techniques and extension to geological timescales, Chem. Geol., 79, 155-182, 1989.

Hamilton, W. B., Detachment faulting in the Death Valley region, California and Nevada, U.S. Geol. Surv. Bull., 1790, 51-85, 1988.

House, M. A., B. P. Wernicke, K. A. Farley, and T. A. Dumitru, Cenozoic thermal evolution of the central Sierra Nevada, California, from (U-Th) He thermochronology, Earth Planet. Sci. Lett., 151, 167-179, 1997.

House, M. A., B. P. Wernicke, and K. A. Farley, Dating topography of the Sierra Nevada, California, using apatite (U-Th)/He ages, Nature, 396, 66-69, 1998

House, M. A., K. A. Farley, and D. Stockli, Helium chronometry of apatite and titanite using Nd-YAG laser heating, Earth Planet. Sci. Lett., 183 $365-368,2000$

John, D. A., Geologic setting, depths of emplacement, and regional distribution of fluid inclusions in intrusions of the central Wasatch Mountains, Utah, Econ. Geol., 84, 386-409, 1989

John, D. A., Evolution of Hydrothermal fluids in the Alta Stock, central Wasatch Mountains, Utah, U. S. Geol. Surv. Bull., 1977, 51 pp., 1991.

Ketcham, R. A., R. A. Donelick, and W. D. Carlson, Variability of apatite fission-track annealing kinetics, III, Extrapolation to geological time scales, Am. Mineral., 84, 1235-1255, 1999

Ketcham, R. A., R. A. Donelick, and M. B. Donelick, AFTSolve: A program for multi-kinematic modeling of apatite fission-track data, Geol. Mat. Res., 2, 1-32, 2000.

Kowallis, B. J., J. Ferguson, and G. J. Jorgensen, Uplift along the Salt Lake segment of the Wasatch fault from apatite and zircon fission track dating in the Little Cottonwood Stock, Nucl. Tracks Radiat. Meas., 17, 325329, 1990.

Laslett, G. M., A. J. W. Gleadow, and I. R. Duddy, Thermal annealing of fission tracks in apatite, 2, A quantitative analysis, Chem. Geol., 65, $1-13,1987$.

Lippolt, H. J., M. Leitz, R. S. Wernicke, and B. Hagedorn, (Uranium + thorium)/helium dating of apatite: Experience with samples from different geochemical environments, Chem. Geol., 112, 179-191, 1994.

Machette, M. N., S. F. Personius, A. R. Nelson, D. P. Schwartz, and W. R Lund, The Wasatch fault zone, Utah-Segmentation and history of Holocene earthquakes, J. Struct. Geol., 13, 137-149, 1991.

McCalpin, J. P., and S. P. Nishenko, Holocene paleoseismicity, temporal clustering, and probablities of future large $(M>7)$ earthquakes on the Wasatch fault zone, Utah, J. Geophys. Res., 101, 6233-6253, 1996.

Miller, E. L., T. A. Dumitru, R. W. Brown, and P. B. Gans, Rapid Miocene slip on the Snake Range-Deep Creek Range fault system, east-centra Nevada, Geol. Soc. Am. Bull., 111, 886-905, 1999.

Naeser, C. W., B. Bryant, M. D. J. Crittenden, and M. L. Sorensen, Fissiontrack ages of apatite in the Wasatch Mountains, Utah: An uplift study, Mem. Geol. Soc. Am., 157, 29-36, 1983.

Naeser, N. D., C. W. Naeser, and T. H. McCulloh, The application of fission-track dating to depositional and thermal history of rocks in sedimentary basins, in Thermal History of Sedimentary Basins-Methods and Case Histories, edited by N. D. Naeser and T. H. McCulloh, pp. 157-180, Springer-Verlag, New York, 1989

Parry, W. T., and R. L. Bruhn, Pore fluid and seismogenic characteristics of fault rock at depth on the Wasatch Fault, Utah, J. Geophys. Res., 91, $730-744,1986$

Parry, W. T., and R. L. Bruhn, Fluid inclusion evidence for minimum $11 \mathrm{~km}$ vertical offset on the Wasatch fault, Utah, Geology, 15, 67-70, 1987.

Schwartz, D. P., and K. J. Coppersmith, Fault behavior and characteristic earthquakes: Examples from the Wasatch and San Andreas fault zones, J. Geophys. Res., 89, 5681-5698, 1984.

Spencer, J. E., The role of tectonic denudation in the warping and uplift of low-angle normal faults, Geology, 12, 95-98, 1984.

Spotila, J. A., K. A. Farley, and K. Sieh, Uplift and erosion of the San Bernardino Mountains associated with transpression along the San Andreas fault, California, as constrained by radiogenic helium thermochronometry, Tectonics, 17, 360-378, 1998

Stockli, D. F., and J. K. Linn, Apatite fission-track thermochronology of the Canyon Range, Utah: Exhumation of the breakaway zone of the Sevier Desert detachment, Geol. Soc. Am. Abstr. Programs, 28, A-116, 1996.

Stockli, D. F., K. A. Farley, and T. A. Dumitru, Calibration of the apatite (U-Th)/He thermochronometer on an exhumed fault block, White Mountains, California, Geology, 28, 983-986, 2000.

Tagami, T., and C. Shimada, Natural long-term annealing of the zircon fission track system around a granitic pluton, J. Geophys. Res., 101, $8245-8255,1996$

Tagami, T., R. F. Galbraith, R. Yamada, and G. M. Laslett, Revised annealing kinetics of fission tracks in zircon and geological implications, in Advances in Fission-Track Geochronology, edited by P. Van den haute and F. De Corte, pp. 99-112, Kluwer Acad., Norwell, Mass., 1998.

Taylor, A., P. A. Armstrong, and K. A. Farley, Evaluation of the long-term segmentation of the Wasatch Fault footwall using (U-Th)/He Thermochronometry, Eos Trans. AGU, 82(47), Fall Meet. Suppl., Abstract T51B0881, 2001.

Vogel, T. A., F. W. Cambray, L. Feher, and K. N. Constenius, Petrochemistry and emplacement history of the Wasatch igneous belt, central Wasatch Mountains, Utah, Geol. Soc. Am. Abstr. Programs, 29, A-282, 1997.

Warnock, A. C., P. K. Zeitler, R. A. Wolf, and S. C. Bergman, An evaluation of low-termperature apatite U-Th/He thermochronometry, Geochim. Cosmochim. Acta, 61, 5371-5377, 1997.

Wernicke, B., and G. J. Axen, On the role of isostasy in the evolution of normal fault systems, Geology, 16, 848-851, 1988.

Willett, S. D., Inverse modeling of annealing of fission tracks in apatite, 1, A controlled random search method, Am. J. Sci., 297, 939-969, 1997.

Wolf, R. A., K. A. Farley, and L. T. Silver, Helium diffusion and lowtemperature thermochronometry of apatite, Geochim. Cosmochim. Acta, 60, 4231-4240, 1996

Wolf, R. A., K. A. Farley, and L. T. Silver, Assessment of (U-Th)/He thermochronometry: The low-temperature history of the San Jacinto mountains, California, Geology, 25, 65-68, 1997.

Wolf, R. A., K. A. Farley, and D. M. Kass, Modeling of the temperature sensitivity of the apatite (U-Th/He thermochronometer, Chem. Geol., 148, 105-114, 1998.

Yamada, R., T. Tagami, S. Nishimura, and H. Ito, Annealing kinetics of fission tracks in zircon: An experimental study, Chem. Geol., 122, 249258,1995

Zandt, G., and T. J. Owens, Crustal flexure associated with normal faulting and implications for seismicity along the Wasatch Front, Utah, Bull. Seismol. Soc. Am., 70, 1501-1520, 1980.

Zeitler, P. K., A. L. Herczeg, I. McDougall, and M. Honda, U-Th-He dating of apatite: A potential thermochronometer, Geochim. Cosmochim. Acta, $51,2865-2868,1987$.

P. A. Armstrong, Department of Geological Sciences, California State University, Fullerton, P.O. Box 6850, Fullerton, CA 92834, USA. (parmstrong@fullerton.edu)

D. S. Chapman, Department of Geology and Geophysics, University of Utah, 135 S., 1460 E., Salt Lake City, UT 84112, USA. (dchapman@mines. utah.edu)

T. A. Ehlers, Department of Geological Sciences, University of Michigan, 2534 C.C. Little Building, 425 East University, Ann Arbor, MI 48109-1063, USA. (tehlers@umich.edu)

K. A. Farley, Division of Geological and Planetary Sciences, California Institute of Technology, MS 170 25, Pasadena, CA 91125, USA. (farley@gps.caltech.edu)

P. J. J. Kamp, Department of Earth Sciences, University of Waikato, Private Bag 3105, Hamilton, 2001 New Zealand. (p.kamp@waikato.ac.nz) 